NBER WORKING PAPER SERIES

\title{
FIRE IN THE BELLY? EMPLOYEE MOTIVES AND INNOVATIVE PERFORMANCE IN STARTUPS VERSUS ESTABLISHED FIRMS
}

\author{
Henry Sauermann \\ Working Paper 23099 \\ http://www.nber.org/papers/w23099 \\ NATIONAL BUREAU OF ECONOMIC RESEARCH \\ 1050 Massachusetts Avenue \\ Cambridge, MA 02138 \\ January 2017
}

I am indebted to Wes Cohen for many stimulating discussions of this and related projects. I also thank Rajshree Agarwal, Ashish Arora, Jeff Edwards, Jon Fjeld, David Hsu, Nimmi Kannankutty, Steve Klepper, Mike Roach, Paula Stephan, Scott Stern, and Long Vo for their feedback and comments. Support from a Kauffman Foundation Junior Faculty Fellowship is gratefully acknowledged. I thank the National Science Foundation for providing the restricted-use SESTAT database employed in the empirical analysis. However, "the use of NSF data does not imply NSF endorsement of the research methods or conclusions contained in this report." The views expressed herein are those of the author and do not necessarily reflect the views of the National Bureau of Economic Research.

NBER working papers are circulated for discussion and comment purposes. They have not been peer-reviewed or been subject to the review by the NBER Board of Directors that accompanies official NBER publications.

(C) 2017 by Henry Sauermann. All rights reserved. Short sections of text, not to exceed two paragraphs, may be quoted without explicit permission provided that full credit, including () notice, is given to the source. 
Fire in the Belly? Employee Motives and Innovative Performance in Startups versus Established Firms

Henry Sauermann

NBER Working Paper No. 23099

January 2017

JEL No. J24,O31,O32

\begin{abstract}
We examine whether startups attract employees with different pecuniary and non-pecuniary motives than small or large established firms. We then explore whether such differences in employee motives lead to differences in innovative performance across firm types. Using data on over 10,000 U.S. R\&D employees, we find that startup employees place lower importance on job security and salary but greater importance on independence and responsibility. Startup employees have higher patent output than employees in small and large established firms, and this difference is partly mediated by employee motives - especially startup employees' greater willingness to bear risk. We discuss implications for research as well as for managers and policy makers concerned with the supply of human capital to entrepreneurship and innovation.
\end{abstract}

Henry Sauermann

Scheller College of Business

Georgia Institute of Technology

Atlanta, GA 30308

and NBER

henry.sauermann@scheller.gatech.edu 


\section{INTRODUCTION}

At least since Schumpeter (1942), scholars have studied what role startups and established firms play in generating technological advance, and what advantages some types of firms may have over others in generating innovation (Acs \& Audretsch, 1990; Agrawal et al., 2014; Arora et al., 2009; Gans et al., 2002; Lowe \& Ziedonis, 2006; Zenger, 1994). This research has made considerable progress by studying firm level-factors such as differences in resources, coordination costs, or economies of scale (Cohen, 2010). Even though individual employees are typically responsible for a large part of the innovative activity inside firms, however, little work has examined whether startups and established firms differ with respect to the characteristics of their human capital, especially employees' motives (Cohen \& Sauermann, 2007). The lack of attention to employee motives is particularly surprising given that entrepreneurship research has highlighted important differences in the motives and incentives of founders compared to those of managers and employees working in large established firms (e.g., Amit et al., 2001; Astebro \& Thompson, 2011; Shane et al., 2003). Moreover, there is increasing evidence that these founder motives have important implications for outcomes such as entry decisions, strategic choices, firm survival, and competitive dynamics (Arora \& Nandkumar, 2011; Ding, 2009; Morton \& Podolny, 2002). It seems natural to extend this line of research and ask if startup employees also differ from their counterparts in established firms, and whether such differences may lead to differences in performance.

We begin to address these questions by comparing employees' pecuniary and nonpecuniary motives between startups and established firms and by examining whether differences in employee motives lead to differences in innovative performance across types of firms. To ground our inquiry, we outline a conceptual model that integrates three building blocks. First, we draw on work in organizational theory and economics to consider structural characteristics and constraints that condition the job attributes different types of firms are able to provide to their employees. While prior work has examined such attributes focusing on either firm size or age, startups may have unique profiles since they are both small and young (see Burton et al., 2016; Haltiwanger et al., 2013). Second, the literature on labor market sorting argues that firms offering different types of job attributes should attract workers with different motives (Agarwal \& Ohyama, 2013; Rosen, 1986), suggesting that startup employees may differ systematically from 
those joining small or large established firms. Finally, we relate employees' motives to innovative performance within and across firms. In doing so, we draw on research suggesting that motives may condition not only levels of effort but also the productivity of that effort in generating innovative outcomes (Amabile, 1996; Ouimet \& Zarutskie, 2014; Sauermann \& Cohen, 2010). Taken together, we suggest that startups offer different job attributes than established firms and thus attract employees with different sets of motives. These differences in employee motives, in turn, may mediate differences in innovative performance.

We examine these relationships using the National Science Foundation's Science and Engineering Statistical Data System (SESTAT). Drawing on data from over 10,000 U.S. scientists and engineers working in startups and established firms, we find significant differences across firm types with respect to employees' pecuniary as well as non-pecuniary motives. Differences in security motives emerge along both the firm size and firm age dimensions, while differences with respect to other motives such as autonomy and salary emerge primarily along firm size. Startup employees have more patent applications than employees in small or large established firms, a difference that is associated with firm age rather than firm size. Using a series of regression analyses, we find evidence that employee motives partially mediate the relationship between firm types and innovative performance. Rather than intrinsic motives or the quest for money, however, employees' willingness to bear risk seems to play the most important role. We conduct robustness checks to address endogeneity concerns and alternative explanations.

This paper makes several contributions. First, we contribute to the entrepreneurship literature by providing unique insights into the motives of startup employees and how they compare to those of employees in small and large established firms. While a large body of work has examined the characteristics of founders (e.g., Amit et al., 2001; Eesley \& Roberts, 2012; Hamilton, 2000; Hsu et al., 2007; Shane et al., 2003), little work has studied the characteristics of those individuals who join founders in their entrepreneurial efforts. This lack of attention to "joiners" is particularly problematic in the context of technology-based ventures, where early employees are critical for firm success but founders often face difficulties attracting the "right" human capital (Burton, 2001; Neff, 2012; Roach \& Sauermann, 2015; Roberts, 1991). By showing significant differences in employee characteristics between startups and established firms, our study highlights the value of future research on startup employees as a distinct group of employees and as important entrepreneurial actors. 
Second, we contribute to the literature on human capital in knowledge-intensive settings. Most of the existing work in this domain focuses on ability or experience as key individual characteristics (Agarwal et al., 2009; Braguinsky et al., 2012; Campbell et al., 2012; Toole \& Czarnitzki, 2009). We add to this literature by examining employee motives, which are typically hard to observe but may have important implications for labor market choices and performance, even controlling for ability (see also Agarwal \& Ohyama, 2013; Stern, 2004). Our results suggest that a broader conceptualization of human capital as encompassing both ability and motivational factors may result in a more complete understanding of individuals' role in shaping important processes and outcomes within and across organizations.

Finally, our discussion contributes to a large body of innovation literature that has examined performance differences across firms of different size or age (see Cohen, 2010). Most of the existing work has focused on firm-level correlates of size and age such as resources or coordination costs, yet little attention has been paid to characteristics of the individuals who actually perform innovative activities in firms. Scholars have recently begun to examine differences in the ability of employees across the firm size distribution (Elfenbein et al., 2010; Zenger \& Lazzarini, 2004 ) and we add unique insights into employees' pecuniary and non-pecuniary motives. Moreover, our results suggest that firm age and size have different relationships with motives and innovative outcomes, highlighting the need to consider both firm size and age in future work.

\section{CONCEPTUAL BACKGROUND}

\section{Job Attributes and Sorting Based on Motives}

We start from the premise that different types of organizations offer different bundles of pecuniary and non-pecuniary job attributes such as pay, intellectual challenge, or job security. Prospective employees, in turn, differ with respect to their preferences for these job attributes, whereby a stronger preference ("motive") increases the utility they derive from a unit of the corresponding attribute (Stern, 2004). In line with prior research, we consider motives to be relatively stable and "trait-like", i.e., heterogeneity in motives exists even before workers join particular employers (Cable \& Edwards, 2004; Halaby, 2003; Hwang et al., 1998; Killingsworth, 1987).

Given heterogeneity in job attributes and motives, different types of organizations should attract employees with different motives (Agarwal \& Ohyama, 2013; Stern, 2004). We illustrate this sorting mechanism using a simple example. Consider two jobs $(\mathrm{j}=1$ and 2$)$ that offer differ- 
ent levels of pay and a nonpecuniary attribute (e.g., freedom). Assume that job 1 is high on pay but low on freedom (e.g., pay $_{1}=2$, free ${ }_{1}=1$ ), while job 2 is low on pay and high on freedom (e.g., $\operatorname{pay}_{2}=1$, free $\left.2=2\right)$. Now consider two job seekers $(i=1$ and 2$)$ that differ in their motives such that individual 1 has a strong preference for pay and a weak preference for freedom (e.g., prefpay $=2$, preffree $_{1}=1$ ), while individual 2 has a weak preference for pay and strong preference for freedom (e.g., prefpay $_{2}=1$, preffree ${ }_{2}=2$ ). Assuming a simple weighted additive utility function (Stern, 2004), the respective (expected) utilities are $U_{i j}=$ prefpay $_{i}{ }^{*}$ pay $_{j}+$ preffree $_{i}{ }^{*}$ free $_{j} . J_{o b} 1$ is relatively more attractive than job 2 for individual $1\left(U_{11}=5\right.$ vs. $\left.U_{12}=4\right)$, while job 2 is more attractive for individual $2\left(\mathrm{U}_{21}=4\right.$ vs. $\left.\mathrm{U}_{22}=5\right)$. Thus, the individual with a strong preference for pay is likely to sort into the job that offers higher pay, while the individual with a strong preference for freedom will choose the job that offers a higher level of freedom. ${ }^{1}$ As such, while the two individuals face the same trade-offs between pay and freedom inherent in the two jobs, they resolve these tradeoffs differently given their different preferences. While individual 1 feels that it is worth giving up one unit of freedom for an additional unit of pay, individual 2 finds it advantageous to give up one unit of pay for an additional unit of freedom (see also Sauermann \& Roach, 2014). ${ }^{2}$

Although this example illustrates the process of sorting from individuals' perspective, our primary interest is in the resulting systematic differences between the employee populations observed in different types of organizations. In particular, organizations offering higher levels of a particular job attribute should employ workers with stronger preferences for this attribute than organizations that offer lower levels of the attribute. In other words, differences in organizations' characteristics lead - via sorting - to differences in the motives of their employees. In the next section, we discuss more concretely potential differences in the job attributes offered by startups and established firms, as well as resulting differences in employees' motives.

\footnotetext{
${ }^{1}$ We focus on individuals' choices of jobs and abstract from demand side conditions. Agarwal and Ohyama (2013) develop a model of two-sided matching with similar qualitative predictions. Also consistent with our predictions, other models suggest that firms with advantages in offering particular types of job attributes match with workers who place a high value on these job attributes (see Hwang et al., 1998; Stern, 2004). A key driver of this positive assortative matching is the complementarity between preferences and job attributes in the utility function (Becker, 1973; Kryscynski et al., 2014).

${ }^{2}$ In our example, sorting allows both workers to derive similar levels of utility even though (in fact, because) these jobs offer different job attributes. This is not a general result. For example, if workers differ in ability and jobs offer higher levels of job attributes to high ability workers (Stern, 2004), then high ability workers will enjoy higher utility than low ability workers.
} 


\section{Differences in Job Attributes and Motives Between Startups and Established Firms}

We now consider more systematically how jobs in startups - firms that are young and small - may differ from jobs in other types of firms, and what kinds of workers they might attract. While there is little work on job attributes in startups per se, we can draw on prior work that has tied job attributes to either firm size or firm age. The following discussion will show that priors with respect to some job attributes are quite strong. For other attributes, however, conflicting arguments can be made, and it is not clear whether startups offer higher or lower levels. As such, we do not make formal predictions but review key arguments to set the stage for the subsequent empirical analysis asking whether and how employee motives in startups differ from those in small or large established firms.

Our discussion focuses on five job attributes and corresponding motives: Financial income, job security, independence, responsibility, and intellectually challenging work. We focus on these particular attributes for a number of reasons. First, they include both pecuniary and nonpecuniary attributes, consistent with a significant body of work recognizing that employees value a broad range of financial but also nonfinancial payoffs (Amabile et al., 1994; Cable \& Edwards, 2004; Rosen, 1986). Second, these motives have been the focus of emerging work on "joiners", individuals who join founders as startup employees (Neff, 2012; Ouimet \& Zarutskie, 2014; Roach \& Sauermann, 2015). Finally, these motives have been found to be particularly important to knowledge workers and have been linked to innovative performance (Amabile, 1996; Byron \& Khazanchi, 2012; Gambardella et al., 2015; Sauermann \& Cohen, 2010), which is particularly important given our interest in motives as mediators of differences in innovative performance. While these five motives may not capture all relevant reasons why workers sort into startups, and may not capture all motivational characteristics that matter for innovation, they are motives that likely matter for both sorting and innovation. ${ }^{3}$

Startups and established firms may differ most strongly with respect to the job security they can offer to their employees. Firms become more stable over time and survival rates tend to increase with firm age (Carnahan et al., 2011; Carroll \& Hannan, 2000; Jovanovic, 1982). Similarly, large firms have higher survival rates than small firms to the extent that they can draw on

\footnotetext{
${ }^{3}$ This is not to say that future work should be limited to these five motives. Other motives that may play an important role for innovation and entrepreneurship include desires for advancement, contribution to society, or having an impact (Bode et al., 2015; Sauermann et al., 2016). Related work has also looked at broader personality traits such as openness to new experiences (Hamilton et al., 2014).
} 
slack resources, economies of scale, or higher degrees of diversification (Agarwal \& Audretsch, 2001; Brown \& Medoff, 2003; Evans \& Leighton, 1989). More stability and higher chances of firm survival, in turn, should translate into higher levels of job security for employees. Differences in job security offered by startups and established firms are very salient to prospective workers. For example, Roach and Sauermann (2010) asked a sample of U.S. science and engineering $\mathrm{PhD}$ students about their expectations regarding job attributes in startups versus established firms, and their respondents expected significantly higher job security in the latter. Similarly, Neff (2012) provides rich qualitative insights into the important role of risk and security concerns in workers' decisions to join startups during the dotcom era. Overall, our discussion suggests that job security increases with both firm size and firm age, and that startups offer the lowest levels of job security. Assuming that workers sort with respect to their corresponding preferences, we expect that employees working in startups have a lower preference for job security than employees working in small or large established firms.

A second job attribute that figures prominently in the literature is financial income. Studies using general population samples show that large firms offer higher wages than small firms (Burton et al., 2016; Idson \& Feaster, 1990; Oi \& Idson, 1999). Possible explanations for this wage premium include higher levels of resources and thus ability to pay, as well as lower levels of certain nonpecuniary job attributes, resulting in a need to pay compensating differentials. Similarly, some studies suggest that older firms pay higher salaries than young firms although this relationship weakens once differences in employee ability are taken into account (Bengtsson \& Hand, 2013; Brown \& Medoff, 2003). Lower levels of salary in small and young firms may be partly offset by higher levels of variable pay. In particular, small firms may provide stronger performance-contingent incentives to the extent that they are better able to observe individual workers' output (Zenger \& Lazzarini, 2004). Similarly, young firms may have a higher potential for growth and development and may promise higher financial returns in the future (e.g., via stock options). Thus, while startups and established firms may differ with respect to the structure of payments that can be obtained by employees, it is not clear how much they differ with respect to overall levels of financial income and it is important to examine empirically whether and how employees working in different types of firms differ with respect to their financial motives.

Several arguments suggest that startup employees may enjoy higher levels of autonomy and independence than employees in large firms. Organizational theorists argue that larger or- 
ganizations are more bureaucratic and routinized (Idson, 1990; Sorensen, 2007), which may reduce individuals' autonomy and sense of independence. An alleged "conflict" between scientists' desire for autonomy and the bureaucratic management systems of the large business enterprise has also received considerable attention in prior innovation literature (Kornhauser, 1962; Lacetera, 2009; Ritti, 1968). Consistent with these arguments, Benz and Frey (2008) show that workers in small firms derive greater "procedural utility" (job satisfaction from freedom and self-determination) than workers in large firms. Assuming that job seekers sort with respect to their corresponding preferences, we expect that employees working in startups have a higher preference for independence than employees working in large firms.

A growing stream of research focuses our attention on responsibility for a wide range of tasks as a potentially important job attribute (Astebro \& Thompson, 2011; Elfenbein et al., 2010; Lazear, 2005). It is likely that employees in small firms have fewer opportunities to specialize in particular aspects of $R \& D$ and may also have to handle non-R\&D tasks in addition to their $R \& D$ work (see Sorensen, 2007). Early qualitative evidence is provided by Cooper (1966), who finds that R\&D employees in small firms tend to be "generalists" while those in large firms focus on particular aspects of a given project. More recently, Elfenbein et al. (2010) showed that employees working in small firms engage in a broader range of activities than those working in large firms, including technical but also business and managerial tasks. Assuming that workers sort with respect to their preferences, we expect that employees working in startups have a higher preference for responsibility than employees working in large firms.

Finally, we turn to "intrinsic" work benefits such as exciting work and intellectual challenge. Such benefits may take different forms in different domains; for scientists and engineers, challenges related to solving difficult and new technical problems should be most relevant (Amabile et al., 1994; Sauermann \& Cohen, 2010). Popular accounts of the early startup cultures of firms such as Google or Apple suggest that startups can provide scientists and engineers with very exciting and challenging work (Freiberger \& Swaine, 1984; Vascellaro \& Morrison, 2008). Indeed, new firms are often the ones that introduce new technologies into the market (Prusa \& Schmitz, 1991), suggesting that they may provide their technologists with more challenges than established firms. At the same time, many important technical advances are made by large established firms, some of which invest considerable resources in "blue sky" research (Rosenberg, 1990). Thus, it is not clear whether startups offer higher levels of intellectual challenge to their 
scientists and engineers than established firms and, as such, whether startup employees differ from those in established firms with respect to their desires for intellectual challenge.

\section{Differences in Motives as Drivers of Differences in Innovative Performance}

Empirical insights into employee motives may result in a better understanding of the human capital available to different types of firms. Moreover, to the extent that employees' motives shape innovative activities or performance, differences in motives may lead to differences in innovative performance across firm types. In the following, we briefly review prior evidence on the relationships between motives and innovation and discuss what these relationships may imply for the innovative performance in startups versus established firms.

First, social psychologists argue that intrinsic motivation based on autonomy and intellectual challenge is more conducive to creativity than extrinsic motivation based on financial rewards because intrinsically motivated individuals explore a larger solution space and are less likely to seek quick but possibly inferior solutions. In contrast, financial rewards are tied to external evaluation, which may lead to conformity with existing standards and reduce creativity (Amabile, 1996). Thus, individuals who are driven by intrinsic motives and who value autonomy may be more creative. Other scholars, however, argue that even extrinsic motivation may be conducive to creativity if the reward system explicitly specifies novelty as an objective (Byron \& Khazanchi, 2012; Eisenberger \& Shanock, 2003). Thus, while there is agreement that intrinsic motivation is particularly beneficial for innovation, the role of extrinsic motivation remains debated. Existing empirical evidence often relies on laboratory studies that do not necessarily generalize to firm R\&D (Shalley et al., 2004). In a recent paper, Sauermann and Cohen (2010) study industrial scientists and find a strong relationship between intrinsic motives and innovative performance, while motives related to pay had a weaker - though still positive - effect. ${ }^{4}$

Second, risk aversion and security motives may have a negative impact on innovative performance. Innovation involves experimentation with new elements, but the success of these experiments, both in terms of achieving technological goals and in terms of acceptance by the

\footnotetext{
${ }^{4}$ A related stream of work examines the impact of extrinsic incentives on motivation, suggesting that contingent rewards may undermine or "crowd-out" intrinsic motivation (Deci et al., 1999; Frey \& Jegen, 2001). The focus of that literature is primarily on the impact of organizationally provided financial incentives on workers' levels of effort. In contrast, the work we draw on suggests that different types of motivations may also have different implications for the direction of workers' effort (e.g., what projects they pick, how they search for solutions). Our data include a proxy for the level of effort, allowing us to explore the degree to which motives impact performance via the level of effort versus the direction of effort.
} 
market or other evaluators, is uncertain (Simonton, 2003). In addition, novel approaches to problems often yield more uncertain outcomes including a higher likelihood of outstanding results but also a higher risk of failure (Wang et al., 2016). As such, individuals who seek to minimize risks may select "safer" projects and well-established approaches that are less likely to fail but are also less likely to produce high innovative performance (Amabile \& Gryskiewicz, 1987; Dunbar, 1995; Friedman \& Foerster, 2005).

Overall, this discussion suggests that nonpecuniary motives related to challenge and independence are particularly conducive to creativity and innovation, while motives related to salary and especially job security may have less positive or even negative relationships with innovation. To the extent that startups and established firms attract employees with different motivational profiles, differences in these motives may thus lead to differences in innovative performance. Interestingly, a similar link between employee motives and firm performance is implicit in recent work studying the characteristics of startup human capital. In particular, Ouimet and Zarutskie (2014) find that startups employ younger workers and conjecture that younger employees may be less risk averse and select riskier projects. Consistent with this conjecture, the authors show that firms with younger employees exhibit higher growth but also higher failure rates. In contrast to that study, we focus not on demographic characteristics but directly on employee motives - including risk preferences but also preferences for a range of other job attributes - and the question whether differences in employee motives between startups and established firms lead to differences in innovative performance.

\section{DATA AND MEASURES}

\section{Data}

We analyze data from the Scientists and Engineers Statistical Data System (SESTAT), developed by the National Science Foundation. The sample population includes individuals who have a college degree or higher and who are either working in a science and engineering occupation or who are trained in related fields. Most data were collected via a mailed questionnaire; a 
smaller number of questionnaires were administered by telephone, in personal interviews, and via the Internet. Response rates for the SESTAT component surveys ranged from $60-80 \%{ }^{5}$

Our analyses use data from 10,585 respondents included in the SESTAT 2003 who hold a Bachelors, Masters, or $\mathrm{PhD}$ degree and who are full-time employees in for-profit firms. The largest industries in the sample are computer systems design, scientific R\&D services, semiconductors, aerospace, telecom services/internet, chemicals, and pharmaceuticals. Since we are primarily interested in innovative activities and performance, we restrict the sample to respondents who indicate that their primary type of work is basic research, applied research, development, design, or computer applications.

\section{Key Dependent and Independent Variables}

Firm type: Respondents indicated the size of their employer in terms of the number of employees in all locations combined. Respondents indicated one of eight size classes: 10 or fewer employees, 11-24, 25-99, 100-499, 500-999, 1000-4999, 5000-24999, and 25000+ employees.

Respondents also indicated whether their employer came into being as a new business within the past 5 years. We use firm age and size to define three firm types: (1) Startup (new business, size $<100$ employees); (2) Established small firm (old business, size $<100$ ); and (3) Established large firm (old business, size $\geq 100$ ). ${ }^{6}$ Overall, 580 respondents work in startups, 1,059 in established small firms, and 8,946 in established large firms. In addition to using firm age and size to define the three firm types, we also use these dimensions separately in our regression analyses.

Innovative performance: Each respondent reported the number of U.S. patent applications in which he or she was named as an inventor over the last 5 years prior to the survey. We recognize that patent applications are an imperfect measure of innovative performance. In particular, not all inventions are patented and patent propensity may differ across industries, scientific fields, and different types of R\&D (Cohen et al., 2000; Sauermann \& Stephan, 2013). To mitigate this concern, we control for industry, scientific field, and type of R\&D (see Table 1).

\footnotetext{
${ }^{5}$ For more information on the SESTAT data, including the survey instruments, see http://sestat.nsf.gov. While SESTAT data are available for years after 2003, NSF did not consistently collect measures of individuals' motives, performance, or of firm age. ${ }^{6}$ Our definition of startups as $<6$ years and $<100$ employees is consistent with recent empirical work on small firm or startup employment (Campbell et al., 2012; Elfenbein et al., 2010). We will not use the cases working in young and large firms (n=341) because firms in this group tend to be spinoffs from older corporations. In those cases, legal age differs from the age of the business as an organization, which is the focus of our theoretical discussion (see also Burton et al., 2016; Haltiwanger et al., 2013).
} 
Motives: Respondents were asked to rate the importance of a list of different job attributes in response to the following question: "When thinking about a job, how important is each of the following factors to you...?". The attributes and their respective importance measures are "job security", "salary", "degree of independence", "level of responsibility", and "intellectual challenge". Economists routinely assume individuals' motives and preferences to be exogenous, and many social psychologists consider motives to be largely stable and "trait-like" (see Agarwal \& Ohyama, 2013; Amabile et al., 1994; Cable \& Edwards, 2004; Stern, 2004). However, we will also explore potential changes over time in supplementary analyses.

A concern with measures using the same scale is that correlations may be inflated due to common methods bias (Podsakoff et al., 2003). The correlations between motives range from 0 (salary and challenge) to 0.44 (responsibility and independence), suggesting that the measures capture distinct constructs. More importantly, common methods bias is unlikely to affect the relationships between our key dependent and independent variables since they were measured using different types of scales, include subjective as well as objective measures, and were placed in different sections of the survey instrument.

We also need to consider potential social desirability bias, i.e., that respondents might inflate ratings of motives that they think are socially desirable and give artificially low scores to motives that may seems less socially desirable (Moorman \& Podsakoff, 1992). The survey was completely anonymous, and the question on motives was separated from questions on other key variables (firm size, age, and patenting), making it unlikely that respondents changed their responses specifically to justify or rationalize particular choices or outcomes. There is also little reason to believe that social desirability bias differs systematically by firm type, or is systematically related to innovative performance. Despite their potential limitations, the measures of motives provide unique insights into typically unobserved individual characteristics and allow us to compare motives across different types of firms using a standardized measurement approach.

Job attributes: SESTAT includes proxies for two job attributes featured in our conceptual discussion. First, the survey records respondents' basic annual salary, excluding bonuses or overtime pay (unfortunately, SESTAT does not include information about variable pay or stock options). Second, respondents indicated which of 9 non-R\&D work activities occupied more than $10 \%$ of their time (including accounting, employee relations, management, production, profes- 
sional services, sales/marketing, quality management, teaching, other). We use the count of nonR\&D activities as a proxy for the range of respondents' responsibilities in their jobs.

Ability and knowledge: We use several measures to proxy for ability, skills, and experience. First, we follow prior work by using educational attainment (Brown \& Medoff, 1989; Zenger \& Lazzarini, 2004), coding a set of dummy variables indicating whether a respondent's highest degree was a Bachelors, Masters, or PhD. To further control for the quality of education, we include a set of dummy variables indicating the Carnegie ranking of the degree granting institution (e.g., research 1, research 2, or liberal arts). Formal education should be a particularly relevant measure of ability in R\&D, where performance depends critically on domain-relevant technical and cognitive skills and on substantive knowledge (Amabile, 1996; Fleming, 2001). Measures of educational attainment may also reflect innate differences in ability and intelligence to the extent that high ability individuals choose more demanding programs or top tier institutions selectively admit students with higher ability. Finally, we use a survey measure asking respondents how related their current work is to the field of their highest degree, rated on a 3-point scale (from "not related" to "closely related"). This measure proxies for the relevance of skills and knowledge (Ohyama, 2015; Stenard \& Sauermann, 2016).

\section{Additional Variables and Measures}

We include a range of additional variables to control for heterogeneity across industries, employers, individuals, as well as the nature of respondents' work (see Table 1). As such, many potential confounds are explicitly controlled for. We consider potential remaining sources of endogeneity in robustness checks.

Table 1 about here

\section{RESULTS}

\section{Motives in Startups and Established Firms}

Table 2 compares motives across the three types of firms. We find that startup employees consider challenge, independence, and responsibility significantly more important than do employees in established large firms. At the same time, startup employees rate salary and job security significantly lower (mean differences tested using ordered logistic regressions). Differences between employees in startup versus established small firms are smaller and only the security 
motive is significantly different, with a lower rating in startups. To complement this comparison of absolute levels of motives, we create a set of relative measures by computing the difference between the motives regarding salary, independence, responsibility, and challenge on the one hand, and job security on the other. These measures indicate how much stronger (or weaker) each of the four motives is compared to job security. Figure 1 plots these differences for the three firm types and again shows that the profiles of employee motives are very different. For example, while startup employees rate salary, responsibility and challenge significantly more important than security, employees in large established firms rate independence and responsibility significantly less important than security.

Figure 1 about here

We estimate ordered logistic regressions to examine differences in employees' motives across firm types while controlling for demographic characteristics as well as proxies for ability and knowledge (Table 3). Models 1-5 show that compared to startup employees, employees in large established firms report significantly stronger preferences for job security and salary, but weaker preferences for independence and responsibility. To illustrate the effect size, the odds that employees in large established firms rate job security "very important" (vs. not "very important") are more than twice the odds for startup employees (Odds Ratio 2.11). The corresponding expected probabilities are $41 \%$ for startup employees compared to $59 \%$ for employees in large established firms. The differences with respect to other motives are considerably smaller in magnitude. Comparing the motives of startup employees with those of employees in small established firms, we find only one significant difference: The latter have a 1.55 times higher odds of rating job security "very important" compared to startup employees, corresponding to probabilities of 51\% vs. 41\%. Finally, re-estimating regressions with small established firms as the omitted firm type also informs us about differences in employee motives between small and large established firms (not shown in Table 3): Employees in large established firms have significantly stronger security motives $(\mathrm{OR}=1.36)$, weaker independence motives $(\mathrm{OR}=0.85)$, and weaker responsibility motives $(\mathrm{OR}=0.87)$ than employees working in small established firms.

In models 6-10 we further explore differences in motives by using firm age (dummy variable indicating that employer is older than 5 years) and firm size as separate dimensions. Security motives increase with both firm age and size, consistent with our conceptual discussion that 
both age and size may translate into more job security for employees. Using a series of dummies for firm size classes allows us to see that the effect of firm size levels off for firms in the 500-999 category, with no further increase in security motives in larger firms. While security motives are strongly related to both firm age and size, the differences with respect to other motives appear only along the firm size dimension and are smaller in magnitude. ${ }^{7}$

Overall, we find significant differences in employee motives across firm types. Most notably, startup employees report significantly weaker security motives than employees in small and especially large established firms, perhaps reflecting a greater willingness to bear risk. Differences with respect to salary, independence, and responsibility motives emerge primarily along the firm size dimension; these motives do not differ significantly with firm age.

--------- Tables 2 and 3 about here ---------

\section{Job Attributes across Firm Types}

The data allow us to probe differences across firm types with respect to salary as well as responsibility for a broader range of tasks. Model 1 in Table 4 estimates differences in (Ln) salary using OLS. We find no significant difference between startups and established large firms, but significantly lower salary in established small firms than in startups or established large firms. To examine potential differences in the distribution of salary, models 2-4 estimate salary differences across firm types at the $10^{\text {th }}, 50^{\text {th }}$, and $90^{\text {th }}$ percentile of the salary distribution using quantile regression. The results show an intriguing pattern. In particular, salaries at the low end of the distribution $\left(10^{\text {th }}\right.$ percentile $)$ are significantly lower in startups than in established large firms, while they do not differ at the median. At the top end of the distribution, salaries are significantly higher in startups. Thus, scientists and engineers in startups earn similar average pay as those in established large firms, but the pay distribution in startups is wider. Model 5 uses firm age and size as separate dimensions and shows that pay increases with firm size, with a roughly $20 \%$ premium for employees in the largest firms. Controlling for firm size, scientists and engineers working in old firms receive roughly $10 \%$ lower pay than those in young firms. These offsetting

\footnotetext{
${ }^{7}$ We also constructed a continuous firm size measure using the log of the midpoints of the size categories and used this measure to explore potential interactions between firm size and age. However, we find no significant interactions in the regressions of motives or of job attributes and performance. As such, while differences in motives emerge along both the size and the age dimension, these differences tend to be additive and we find no evidence of moderating effects.
} 
effects of firm size and age explain why pay levels in startups do not differ significantly from those in established large firms (as seen in Model 1). ${ }^{8}$

Model 6 examines differences in job responsibilities, as proxied by the number of nonR\&D work activities. Negative binomial regressions show that scientists and engineers in large established firms engage in roughly $17 \%$ fewer different work activities than employees working in startups or in established small firms. Consistent with the notion that opportunities for specialization are primarily a function of firm size, model 7 shows that the number of non-R\&D activities decreases with firm size but has no relationship with firm age. The detailed firm size dummies again reveal nonlinear effects, with coefficients stabilizing around a firm size of 500-999.

Table 4 about here

\section{Innovative Performance in Startups versus Established Firms}

We now examine whether differences in employee motives across firm types are associated with differences in innovative performance. Our performance regressions use the count of patent applications as the dependent variable and are estimated using negative binomial regression to account for overdispersion (Table 5).

Model 1 includes only control variables - including proxies for ability and relevant knowledge - as well as the firm type dummies. Compared to startup employees, researchers in established small firms have 51.9\% lower patent application counts and researchers in large established firms have 29.8\% lower counts. Model 2 adds individuals' motives and shows that challenge and independence motives have a significant positive relationship with output (Incidence Rate Ratio $>1$ ), while security motives have a negative relationship (IRR $<1$ ). These observations confirm prior findings (Sauermann \& Cohen, 2010) and are consistent with the notion that intrinsic motives are particularly conducive to creativity while risk aversion and a concern with failure may reduce the scope of search and lead individuals to pursue safer but also potentially less novel projects and approaches (Amabile, 1996; Ouimet \& Zarutskie, 2014).

\footnotetext{
${ }^{8}$ Recent work using Danish general population data also shows a positive relationship of wages with firm size but a negative relationship with firm age. In that study, however, the size effect outweighs the age effect for most people, leading to lower wages in small and young firms (Burton et al., 2016). In contrast, Kim (2016) finds no wage difference between VC-backed startups and established firms once individuals' ability is controlled for. Consistent with our quantile regressions, these results suggest that wage differences may depend on the sample studied, with less of a discount (or even a premium) for startup employees in upper parts of the ability distribution.
} 
However, our focus is not on the relationships between motives and performance per se, but on the degree to which employee motives mediate the relationship between firm types and innovative performance. In particular, if the motives typical of startup employees are more beneficial than those of employees in established firms, the estimated performance differences between firm types should be reduced once differences in motives are accounted for. One approach to test mediation is, therefore, to test the change in firm type dummies once motives are included (see Baron \& Kenny, 1986; Elfenbein et al., 2010). Consistent with our expectation, the firm type coefficients are significantly reduced in Model 2 (the Incidence Rate Ratios move closer to one; $\left.\mathrm{Chi}^{2}(2)=9.80, \mathrm{p}<0.01\right)$. Especially for established large firms, the change in firm type dummies is also economically significant: The performance gap compared to startups is reduced from $29.8 \%$ to $19.5 \%$ (from $51.9 \%$ to $46.9 \%$ for established small firms). The significant remaining differences between firm types likely reflect a number of other mechanisms that may also mediate differences in patent output (see discussion below). Mediation analyses using the product of coefficients approach detailed in the next section confirm significant mediation by motives and also reveal that security motives have by far the largest effect. The prominent role of security motives as mediator reflects both the large differences in security motives across firm types (see Table 3), and the large negative effect of security motives on innovative performance (Table 5).

Model 3 additionally includes the measure of hours worked. As expected, individuals who work more hours have higher performance. However, the inclusion of this proxy for the quantity of effort leads to no noticeable change in the coefficients of motives, suggesting that motives influence innovative performance primarily by shaping the direction or quality of effort rather than the level of effort (Amabile, 1996; Sauermann \& Cohen, 2010). Nevertheless, accounting for differences in effort further reduces the coefficients of firm types, and the performance difference between startups and established large firms is no longer significant.

Models 4-6 use the firm size and age measures instead of the firm type dummies. Model 4 shows that employees in old firms have significantly fewer patents than those in young firms. While firm size shows no strong relationship with patent counts, employees in the largest firms appear to be somewhat more productive than those in the smallest firms (IRR=1.367, n.s.). Thus, the performance advantage of startups is associated primarily with their young age rather than their small size. When we include individuals' motives (model 5), the coefficient of firm age is significantly reduced $\left(\mathrm{Chi}^{2}(1)=5.69, \mathrm{p}<0.05\right)$, again providing evidence of partial mediation. 


\section{Supplementary Analyses}

\section{Testing Mediation Using the Product of Coefficients Approach}

In the prior section, we provided evidence of mediation using the method popularized by Baron and Kenny (1986). A more powerful method is the product of coefficients approach (Agarwal et al., 2016; Hayes, 2009; Preacher \& Hayes, 2008), which allows us to compute and test mediating effects separately for each of the firm types and for each of the five motives. The idea is that the effect of a variable (X) on an outcome (Y) that is mediated by another variable (M) can be computed by multiplying the coefficient of $\mathrm{X}$ in a regression of $\mathrm{M}$ on $\mathrm{X}$ and the coefficient of $\mathrm{M}$ in a regression of $\mathrm{Y}$ on $\mathrm{M}$ and $\mathrm{X}$. Since this approach has been developed for linear regressions, we use seemingly unrelated regression to estimate five OLS models of motives (our M) that include firm types as the primary independent variables, as well as one regression of the (Ln) patent count that includes both firm types and motives. We then compute for each motive the product of the coefficients in the two equations and obtain confidence intervals for these products using bootstrapping with 5,000 repetitions (Preacher \& Hayes, 2008).

The results shown in Table 6 confirm that employee motives significantly explain lower innovative performance observed in small established firms and in large established firms relative to startups. We also find that the mediating effect is roughly twice as large for large established firms, consistent with our observation that large established firms differ more strongly from startups with respect to employee motives than do small established firms (see Figure 1). Estimates for each of the motives separately show highly significant mediation of job security motives, but no significant effects of the other motives. Thus, while several motives differ across firm types (Table 3), security motives play the primary role in mediating the relationships between firm types and innovative performance.

\section{Table 6 about here}

\section{Potential Changes in Motives over Time}

Our conceptual discussion emphasized ex ante selection mechanisms, i.e., that individuals with strong pre-existing motives sort into organizations that offer high levels of the corresponding job attributes. However, motives were measured at the time of the survey and may also 
have changed ex post due to socialization processes (Allen \& Katz, 1992; Chatman, 1991; Sorensen, 2007). While differences in motives across firm types are important even if they reflect ex post changes, we now seek to gain additional insights into the relative role of ex ante selection versus ex post changes.

A first piece of indirect evidence comes from existing work using samples of scientists and engineers prior to their initial career transitions, i.e., before they were exposed to potential socialization in a particular type of firm. In particular, Roach and Sauermann (2015) surveyed U.S. science and engineering PhD students, collecting measures of both motives and career preferences. The authors found that respondents who were less risk averse and had stronger desires for autonomy found $R \& D$ positions in startups relatively more attractive than positions in established firms. Thus, there is evidence that heterogeneity in motives exists before employment and that motives may have an important role in shaping career choices and sorting.

Second, we estimate regressions of motives separately for individuals working in startups and established large firms and include a variable measuring tenure in the current job. If socialization were to explain our key results, motives related to job security and salary would have to increase with job tenure in large firms, while motives related to independence and responsibility would have to decrease. The opposite pattern would have to be observed in startups. The results (Table S1, models 1-10) show no relationship between job tenure and motives among startup employees. In established large firms, the independence motive increases (rather than decreases) with tenure, suggesting that the observed lower levels of independence motives compared to startups are not due to socialization. At the same time, job security motives increase and challenge motives decrease, consistent with a socialization argument. To assess the magnitude of this effect, we compared differences in security and challenge motives between startups and established large firms for two sets of individuals: those who started their job within the last two years (where socialization effects are likely limited) and those who started more than two years ago (socialization likely stronger). The difference in the share of respondents reporting that job security is "very important" is 16.5 percentage points among those who joined their employer recently (40.8\% vs. $57.3 \%)$, compared to 20.1 percentage points in the older cohort (39.1\% vs. 59.2\%), suggesting that socialization effects are relatively weak compared to selection. For challenge, the difference in the younger cohort is 4 percentage points $(72.9 \%$ vs. $68.9 \%$ "very important" ratings) compared to $9.9(74.1 \%$ vs. $64.2 \%)$ in the older cohort, suggesting that the large firm envi- 
ronment may indeed have a noticeable impact on employees' challenge motives. A caveat in interpreting correlations between tenure in an organization and motives as evidence of socialization is that in a cross-sectional analysis, these correlations may also reflect the selective retention of individuals whose motives are aligned with the organization (Chatman, 1991). Overall, these analyses relating motives to job tenure suggest that the patterns of motives in startups are primarily due to selection rather than socialization. In large established firms, we find no evidence for socialization with respect to independence motives, but security and challenge motives may partly reflect socialization as well as ex post and ex ante selection. Future research using longitudinal data is needed to more clearly identify the role of selection and socialization, and to explore how the motivational characteristics of the workforce change as organizations mature.

We also consider potential endogeneity with respect to performance, e.g., that researchers who are successful begin to care more about challenging work, while those who underperform worry about job security. To explore this possibility, we conduct the following thought experiment: Given that many respondents have no patent application, even having just a small number of patents may indicate good R\&D performance. As such, any reverse effects running from performance to security or challenge motives should occur primarily at the lower end of the performance distribution. In contrast, the mechanisms highlighted in our conceptual discussion - such as the potentially detrimental impact of risk aversion on creativity - should operate across the full range of output, and may even be most pronounced at the high end of the performance distribution. To examine these relationships empirically, Model 1 in Table S2 estimates a probit regression distinguishing respondents without patents and those with 1 patent. Models 2-6 use the sample of individuals with at least 1 patent and estimate a series of quantile regressions ranging from the $30^{\text {th }}$ to the $90^{\text {th }}$ percentile. The results show no significant coefficients of motives in the probit regression, and relatively small coefficients for the lower quantiles. The coefficients of motives - especially of challenge and security - increase in size and significance as we move to higher quantiles. Thus, under the assumption that reverse causality would be more pronounced at the lower end of the performance distribution, our data somewhat mitigate endogeneity concerns. Of course, this analysis is only an initial effort to address endogeneity concerns within the limitations of the SESTAT data; future work is needed to address reverse causality between motives and performance using different data sets and empirical approaches. 


\section{Supplementary Analyses of Performance}

Our measure of innovative performance has a skewed distribution with some individuals reporting a very high number of patent applications. To ensure that our results are not driven by these outliers, we estimate key regressions dropping those cases with more than 20 patent applications. The results are robust (Table S2, models 7-8).

By focusing on employee motives, our discussion thus far has abstracted from other factors that may shape innovative performance across types of firms. We now briefly discuss such additional factors and how they may affect our results. First, sorting of employees is likely to lead to a correlation between motives and corresponding job attributes such as levels of job security, pay, or the range of responsibilities. If these job attributes have an independent impact on performance, our regressions may confound the effects of motives with those of unobserved job attributes. While we do not have the data to account for all potentially relevant job attributes, we can take an initial step by controlling for respondents' salary and non-R\&D responsibilities. Models 9 and 10 in Table S2 show a strong positive coefficient of salary but no effect of the range of non-R\&D activities. More importantly, the coefficients of responsibility and salary motives are not different from the baseline, showing no evidence of a bias due to omission of these two job attributes. ${ }^{9}$ Even though we lack controls for the other three job attributes, we can make a conceptual argument that at least for the security motive - which appears to be the primary mediator - unobserved actual levels of job security are unlikely to drive our results. In particular, while sorting may lead to a positive correlation between security motives and actual levels of job security, it is difficult to see why lower levels of job security in startups would be beneficial for innovation (other than by attracting less risk averse workers). The prior literature suggests exactly the opposite: Organizations seeking to encourage innovation should offer job stability and offer protection against the negative consequences of failing (see Levinthal \& March, 1993; O'Reilly, 1989). Thus, while a weaker concern with security among startup employees is likely to foster exploration and innovation, lower actual job security offered by startups is not.

\footnotetext{
${ }^{9}$ Even with these additional controls, the firm type dummies are significantly reduced once motives are included (model 9 vs. 10 , $\left.\mathrm{Chi}^{2}(2)=7.03, \mathrm{p}<0.05\right)$, consistent with our baseline models. This supplementary analysis should be interpreted with caution because salary may well be endogenous to individuals' prior performance. As such, the coefficients of job attributes (salary in particular) should not be interpreted as reflecting a causal effect of pay or incentive systems on performance. Our goal is merely to assess potential changes in the coefficients of motives once proxies of the corresponding job attributes are included.
} 
One may be concerned that higher innovative performance in startups reflects that startups can be found primarily in nascent technological areas with greater technological opportunities. This possibility should to a large extent be addressed by the inclusion of industry and field fixed effects. In addition, all regressions control for the nature of research (i.e., basic, applied, etc.) and for different sources of funding. We further probe robustness by restricting the sample to firms in industries with high startup activity (i.e., more than $5 \%$ of respondents working in a startup). Regressions 11-12 in Table S2 show that our results hold.

Another possibility is that there are differences in patent propensity, e.g., that startups rely more strongly on patents as a signal of their quality or as a mechanism to appropriate value from inventions (Belenzon \& Pattaconi, 2012; Hsu \& Ziedonis, 2013). Such differences would be captured in the coefficients of firm type dummies in both our baseline regression and in the regression including motives as mediators. However, such differences are unlikely to be related to employee motives and would not explain why firm type dummies change once motives are included or why the product of coefficients approach yields significant evidence of mediation.

An important question is whether observed performance differences across firm types may reflect selection at the firm level. The seminal model developed by Jovanovic (1982) is useful for thinking about this possibility. In this model, young firms start out small, vary in randomly assigned capabilities, and learn about these capabilities over time. Those firms that turn out to possess superior capabilities have an incentive to leverage them and grow, while firms below a certain capability threshold exit. Firms that are good enough to survive but not good enough to grow remain small. By incorporating heterogeneity in firm capabilities, this model provides an explanation for our observation that small established firms perform worse than large established firms and than startups: they may be firms that had a draw from the lower end of the capability distribution and were not good enough to grow. Selection on capabilities does not, however, provide a ready explanation for the observed higher performance in startups compared to large established firms since the latter should be more strongly selected based on superior capabilities than the former (Jovanovic, 1982). While this argument suggests that advantages with respect to employee motives for firms of certain age and size are different from superior firm-specific ex ante endowments in capabilities, it also raises the interesting possibility that attention to job attributes and employee motives may inform our understanding of the evolution of (innovative) capabilities as firms grow and mature. 
Finally, prior work has discussed other factors that may also affect innovative performance across types of firms (e.g., Acs \& Audretsch, 1990; Agarwal \& Audretsch, 2001; Cohen, 2010; Cooper, 1964; Criscuolo et al., 2012; Schumpeter, 1942). Among others, large firms may benefit from better access to financing, scale economies and fixed cost spreading, or complementarities between R\&D and other activities. Small firms may have advantages in R\&D because of easier communication and coordination. Similar to other potential drivers of innovative performance discussed earlier, these factors may be reflected in the firm type dummies estimated in our regressions. However, there is little reason to expect these factors to be correlated with the employee motives featured in our analysis. As such, they are unlikely to explain the observed relationships between motives and innovative performance, or the significant evidence of mediation we find using both the Baron \& Kenny method and the product of coefficients approach.

\section{Relationship with Prior Work}

It is useful to highlight differences and complementarities with particularly relevant related work. A first important study is Elfenbein et al.'s (2010) examination of the phenomenon that small firm employees are more likely to become self-employed in a subsequent period than employees working in large firms. Elfenbein et al. explore a range of possible mechanisms, including the possibility that individuals with a long-standing preference for self-employment first join small firms to then transition into self-employment ("preference sorting"). The Elfenbein et al. study contributes to the entrepreneurship literature by examining employees' transition into subsequent self-employment as the primary outcome of interest, while our study focuses on differences in the characteristics of employees across firm types and how they relate to innovative performance during employment. Moreover, while Elfenbein et al. examine preference sorting by measuring individuals' preference for self-employment, we examine a range of more specific motives such as desires for job security or challenge. Finally, while Elfenbein et al. examine sorting only with respect to firm size, our study distinguishes firm size and firm age, showing that they relate in different ways to both employee motives and to innovative performance.

Our study also relates to work by Sauermann and Cohen (2010), who use a sample of respondents to the Survey of Doctorate Recipients (a component of SESTAT) to show systematic relationships between individuals' motives and innovative performance in industrial $R \& D$. We take this prior evidence as a building block and ask whether motives differ between startups and established firms and whether any such differences lead to differences in innovative performance 
across types of firms. The findings of Sauermann \& Cohen say little about these questions because they do not provide insights into whether and how motives differ across firm types; it is not clear whether any such differences work for or against startups; and it is not clear whether differences in motives across firm types are large enough to translate into significant performance differences. ${ }^{10}$

\section{SUMMARY AND DISCUSSION}

Using data on over 10,000 U.S. scientists and engineers, we examine whether employees' pecuniary and nonpecuniary motives differ between startups and established firms and whether any such differences in motives lead to differences in innovative performance. We find that compared to employees in large established firms, startup employees place a lower value on salary and job security, the latter possibly reflecting a more general willingness to bear risk. On the other hand, startup employees have stronger motives related to independence and responsibility, although these differences are smaller than might be expected. We also find that scientists and engineers in startups have more patent applications than those in small and large established firms, and this performance difference is partially mediated by employee motives.

\section{Limitations and Future Research}

We acknowledge important limitations and resulting opportunities for future research. First, we document significant differences in employee motives across firm types but we made limited progress towards identifying the underlying reasons. While our discussion focused on ex ante selection, we cannot fully distinguish this mechanism from selective retention ex post or from changes in motives during employment. However, related research using samples of individuals prior to labor market entry as well as our own supplementary analyses suggest that ex ante selection plays an important and perhaps dominant role. More importantly, whether due to selection or ex post changes, differences (and similarities) in employee motives in startups versus established firms are interesting and relevant, especially given the lack of attention to motives in

\footnotetext{
${ }^{10}$ The relationships we observe between motives and performance are similar to those in Sauermann \& Cohen (2010). However, likely due to the use of different samples, we observe somewhat stronger relationships between patenting and security motives, and somewhat weaker relationships between patenting and salary and responsibility motives. SESTAT also includes measures of motives regarding advancement and contributing to society. Due to the lack of relationships with performance in Sauermann \& Cohen (2010), the absence of priors regarding systematic differences across firm types, and to limit the complexity of our analyses, we excluded these motives. Robustness checks show that these motives have no relationship with performance and their inclusion does not change our featured results (available upon request).
} 
prior empirical work. Second, we observed significant relationships between employee motives and innovative performance, but the data do not allow us to assess the role of the different mechanisms raised in the conceptual discussion or to conclusively establish the causal relationship between motives and performance. In particular, although we include a broad range of proxies for individuals' ability and relevant knowledge, we cannot rule out that motives are correlated with remaining unobserved heterogeneity in ability and knowledge. Any such correlation, however, would raise intriguing questions regarding the role of unobserved motives in much of the prior literature focusing exclusively on ability without considering motivational characteristics. Third, although the literatures on career choice and innovation highlight the particular motives studied here as particularly important, there may be other motives and individual characteristics that also play an important role. We hope that our findings demonstrate the potential value of studying such individual characteristics and of exploring their potential role in shaping innovative performance in different types of firms. Fourth, while the data include a broad range of individual-level measures, measures of job attributes and firm characteristics are limited. As such, we cannot completely rule out that differences in innovative performance may also reflect remaining unobserved differences in job attributes or firm characteristics. Given the lack of attention devoted to motivational characteristics of human capital, however, it is an important first step to demonstrate empirical patterns that strongly suggest motives as one possible explanation for performance differences across firms. Finally, we measure innovative performance using patent applications, which may reflect not only underlying innovative performance but also firms' strategic choices on whether to patent their inventions. As such, higher rates of patenting observed in startups do not necessarily imply higher rates of innovation. However, firms' patent strategies would not explain the relationships between employee motives and patenting, or why estimated performance differences are reduced when motives are included as a mediator. Nevertheless, future work is needed to replicate our results with other measures of innovation. Indeed, future research could build on our work by studying whether differences in employee motives across firm types may result in differences in important outcomes other than innovation.

\section{Contributions}

Our study makes several contributions. First, we add to recent work on the human capital of entrepreneurial firms by characterizing startup employees with respect to their motives and by comparing them to employees in small and large established firms. Ouimet and Zarutskie (2014) 
provide insights into startup employees' demographic characteristics and conjecture about risk preferences as important correlates; we complement their work using direct measures of preferences for risk as well as a range of other potentially important motives. More importantly, our results suggest that the motivational characteristics of their human capital may provide startup firms with an advantage in innovation, informing a growing literature seeking to understand the role of startups in the larger economy, and potential advantages in innovation in particular (Agarwal et al., 2009; Lerner, 2009; Schramm, 2006). We also add to the entrepreneurship literature by highlighting that startups differ from other firms with respect to both their age and their size and that these two dimensions can have very different relationships with other variables of interest. As such, future research may benefit from considering more explicitly how certain features of startups (e.g., innovativeness, job creation, human capital etc.) result from their young age versus their small size. Future research is needed especially to study what happens as young firms mature. While small firms may stay small, young firms that survive will invariably age and may change with respect to the job attributes they offer (Beckman \& Burton, 2008; Chen et al., 2012). If these changes are inconsistent with the motives of early employees, employees may decide to move and it may be the most "entrepreneurial" and productive employees who are most likely to leave aging firms to join a new venture (Baron et al., 2001; Sorensen, 2007).

Second, we contribute to the literature on the role of human capital in knowledge intensive settings. Much of this literature has focused on ability, skills, and experience and has examined how heterogeneity across individuals or organizations shapes important outcomes such as labor mobility, organizational performance, or the distribution of rents (Agarwal et al., 2016; Agarwal et al., 2009; Campbell et al., 2012; Coff \& Kryscynski, 2011; Rothaermel \& Hess, 2007; Zenger \& Lazzarini, 2004). We complement this work by studying whether and how employee motives differ across different types of firms, and whether such differences explain differences in innovative performance. Our results suggest that a conceptualization of human capital as encompassing both ability and motivational aspects may result in a more complete understanding individuals' role in shaping important processes and outcomes within and across organizations. Such a broader conceptualization of human capital raises a number of interesting questions. For example, while we considered sorting primarily as a result of general structural characteristics such as firm age and size, managers within a given type of firm may have significant latitude in determining job attributes in an effort to attract employees with particular motives. As 
such, research is needed on how firms can more deliberately attract workers with particular motives, and whether doing so can give individual firms a competitive advantage. Similarly, firms may find ways to influence individuals' motives, both to increase performance at a given point in time, but also to retain flexibility if existing motives are inconsistent with desired changes in strategy (Besley \& Ghatak, 2005). Third, it seems important to study the sustainability of competitive advantages based on employee motives. To the extent that motives are difficult to observe by outsiders and relatively stable, competitive advantages may be quite sustainable, perhaps even more so than advantages based on employees' skills and knowledge (Coff \& Kryscynski, 2011; Ganco et al., 2014). Finally, superior performance likely depends on both ability and motivation, and future research could examine their interplay. For example, an interesting question is whether certain kinds of motives may lead some employees to learn faster than others, or to willingly invest in firm-specific knowledge.

Finally, our study contributes to the innovation literature examining performance differences across types of firms (Cohen, 2010). We advance research on the role of firm size and age by linking these firm-level characteristics to specific job attributes and employee motives, thus providing conceptual and empirical insights into micro-level correlates of size and age. Despite the popular notion that employee motives may differ across firm types (Freiberger \& Swaine, 1984; Schumpeter, 1942), empirical evidence regarding the direction and magnitude of such differences has been lacking. Moreover, our analysis suggests that higher rates of patenting are associated primarily with firm age rather than size. Thus, while much prior work on innovation has studied firm size, future work should consider more explicitly the role of firm age and the interplay between size and age.

For managers, our results highlight challenges that established firms may face when seeking to "acqui-hire" human capital by buying innovative startups (Selby \& Mayer, 2013; Younge et al., 2015). If the resulting integration changes job attributes towards those typical of established firms, employees who initially joined a startup because they valued the entrepreneurial environment may soon become disenfranchised and seek to leave. Conversely, our results also suggest potential benefits from creating entrepreneurial units within large firms that explicitly seek to replicate features of young and small organizations.

For policy makers, our results highlight potential advantages of startups not only with respect to job creation (Haltiwanger et al., 2013) but also with respect to innovation. To the extent 
that higher rates of innovation in startups reflect characteristics of their human capital, however, it is not clear that increasing the number of startups per se will yield the greatest dividends: Additional firms may not be able to draw on the same labor supply as existing startups. As such, the most promising policies may relate to the development of science and engineering human capital. Although educational policies currently focus on increasing skills and substantive knowledge, there may be additional benefits from developing mechanisms that help identify and support individuals with motives that are particularly beneficial for entrepreneurship and innovation. Future research on the nature and potential benefits of such policies seems particularly important. 
Table 1: Additional Variables and Measures

\begin{tabular}{|c|c|}
\hline$\underline{\text { Variable }}$ & Description \\
\hline $\begin{array}{l}\text { Quantity of ef- } \\
\text { fort (Hours } \\
\text { worked) }\end{array}$ & $\begin{array}{l}\text { As a proxy for the level of effort, we include the hours worked in a typical } \\
\text { work week, as reported by the respondents. While this measure is likely to be } \\
\text { noisy and may not capture less conscious cognitive effort (e.g., during "show- } \\
\text { er time"), it should be a reasonable proxy (see also Sauermann \& Cohen, } \\
\text { 2010; Zenger \& Lazzarini, 2004). }\end{array}$ \\
\hline $\begin{array}{l}\text { Primary type of } \\
\text { R\&D }\end{array}$ & $\begin{array}{l}\text { Work activity on which the respondent spends the most hours during a typical } \\
\text { work week, including basic research, applied research, development, design, } \\
\text { and computer applications or programming. }\end{array}$ \\
\hline $\begin{array}{l}\text { Funding by } \\
\text { DoD/NASA and } \\
\text { by NIH/NSF }\end{array}$ & $\begin{array}{l}\text { To control for heterogeneity in the nature of research, we include dummies } \\
\text { indicating whether the respondent's projects were funded by the Department } \\
\text { of Defense / NASA or by the NIH/NSF. The former projects may be less like- } \\
\text { ly to be disclosed in patents due to secrecy concerns. Projects funded by } \\
\text { NIH/NSF may be particularly promising. }\end{array}$ \\
\hline $\begin{array}{l}\text { Interactions } \\
\text { with profession- } \\
\text { al community } \\
\text { (Professional } \\
\text { meeting) }\end{array}$ & $\begin{array}{l}\text { Respondents indicated whether they had attended at least one professional } \\
\text { meeting in the last year. We use this proxy to control for heterogeneity in re- } \\
\text { spondents' research orientation and in the degree to which employers pursue } \\
\text { an "open science" strategy, both of which may be related to both motives and } \\
\text { innovative performance (Sauermann \& Roach, 2014; Stern, 2004). This vari- } \\
\text { able may also control for the "cutting edge" nature of research and for re- } \\
\text { spondents' (or firms') desire to demonstrate research capabilities to outsiders. }\end{array}$ \\
\hline Job tenure & $\begin{array}{l}\text { Years since starting the current job, used in auxiliary analysis of potential so- } \\
\text { cialization. }\end{array}$ \\
\hline $\begin{array}{l}\text { Field of highest } \\
\text { degree }\end{array}$ & $\begin{array}{l}\text { Dummy coding for } 19 \text { fields (biochemistry, cell \& molecular biology, micro- } \\
\text { biology, other biology, chemistry, physics, earth sciences, environmental and } \\
\text { health sciences, food sciences, computer science, mathematics, chemical en- } \\
\text { gineering, electrical engineering, mechanical engineering, civil and industrial } \\
\text { engineering, aerospace engineering, materials engineering, other engineering, } \\
\text { and other fields). }\end{array}$ \\
\hline Age & $\begin{array}{l}\text { Employee age in years. Among others, this measure may proxy for the vin- } \\
\text { tage of education, providing an additional control for relevant skills and } \\
\text { knowledge (Ouimet \& Zarutskie, 2014). }\end{array}$ \\
\hline Race/ethnicity & Dummies for Asian, black, Hispanic, white, and other. \\
\hline U.S. citizenship & Dummy coded 1 for U.S. citizens. \\
\hline Marital status & $\begin{array}{l}\text { Dummy coded } 1 \text { for individuals who are married or in a marriage-like rela- } \\
\text { tionship. }\end{array}$ \\
\hline Children & $\begin{array}{l}\text { Count of children under the age of } 18 \text { living in the same household as the re- } \\
\text { spondent. }\end{array}$ \\
\hline $\begin{array}{l}\text { Industry classi- } \\
\text { fication }\end{array}$ & $\begin{array}{l}\text { Dummies for } 28 \text { industries ( } 2 \text { to } 4 \text {-digit NAICS classification). Industry } \\
\text { dummies are intended to control for differences in technological opportunity } \\
\text { and other industry-level conditions affecting R\&D productivity. }\end{array}$ \\
\hline
\end{tabular}


Table 2: Descriptive Statistics by Firm Type

\begin{tabular}{|c|c|c|c|c|c|c|c|}
\hline & \multicolumn{4}{|c|}{$\begin{array}{l}\text { Full Sample } \\
(n=10,585)\end{array}$} & \multirow{2}{*}{$\begin{array}{l}\text { Startup } \\
(n=580) \\
\text { Mean }\end{array}$} & \multirow{2}{*}{$\begin{array}{c}\text { Established } \\
\text { small } \\
(n=1,059) \\
\text { Mean }\end{array}$} & \multirow{2}{*}{$\begin{array}{c}\text { Established } \\
\text { large } \\
(n=8,946) \\
\text { Mean }\end{array}$} \\
\hline & Mean & SD & Min & Max & & & \\
\hline Importance of job security & 3.53 & 0.59 & 1 & 4 & 3.28 & 3.44 & 3.55 \\
\hline Importance of salary & 3.56 & 0.53 & 1 & 4 & 3.48 & 3.51 & 3.57 \\
\hline Importance of independence & 3.48 & 0.59 & 1 & 4 & 3.53 & 3.52 & 3.48 \\
\hline Importance of responsibility & 3.28 & 0.63 & 1 & 4 & 3.34 & 3.30 & 3.28 \\
\hline Importance of intellectual challenge & 3.64 & 0.53 & 1 & 4 & 3.71 & 3.68 & 3.63 \\
\hline Imp. salary-Imp.security & 0.03 & 0.67 & -3 & 3 & 0.20 & 0.07 & 0.02 \\
\hline Imp. independence-Imp.security & -0.04 & 0.81 & -3 & 3 & 0.24 & 0.08 & -0.07 \\
\hline Imp. challenge-Imp. security & 0.12 & 0.78 & -3 & 3 & 0.43 & 0.24 & 0.08 \\
\hline Imp. responsibility-Imp. security & -0.24 & 0.82 & -3 & 3 & 0.06 & -0.14 & -0.27 \\
\hline Patent applications & 1.19 & 4.56 & 0 & 96 & 1.64 & 0.85 & 1.20 \\
\hline Non-R\&D activities & 1.54 & 1.47 & 0 & 8 & 1.66 & 1.79 & 1.50 \\
\hline Salary & 84876 & 36,267 & 10,000 & $500,000 \S$ & 89,450 & 79,256 & 85,244 \\
\hline Ln salary & 11.28 & 0.37 & 9.21 & $13.12 \S$ & 11.30 & 11.18 & 11.29 \\
\hline Firm size: $1-10$ & 0.03 & & 0 & 1 & 0.28 & 0.17 & 0.00 \\
\hline Firm size: $11-24$ & 0.03 & & 0 & 1 & 0.24 & 0.20 & 0.00 \\
\hline Firm size: 25-99 & 0.09 & & 0 & 1 & 0.48 & 0.62 & 0.00 \\
\hline Firm size: $100-499$ & 0.10 & & 0 & 1 & 0.00 & 0.00 & 0.12 \\
\hline Firm size: 500-999 & 0.05 & & 0 & 1 & 0.00 & 0.00 & 0.06 \\
\hline Firm size: $1,000-4,999$ & 0.13 & & 0 & 1 & 0.00 & 0.00 & 0.16 \\
\hline Firm size: 5,000-24,999 & 0.17 & & 0 & 1 & 0.00 & 0.00 & 0.21 \\
\hline Firm size: $25,000+$ & 0.38 & & 0 & 1 & 0.00 & 0.00 & 0.45 \\
\hline Firm age & 0.95 & & 0 & 1 & 0.00 & 1.00 & 1.00 \\
\hline Bachelors & 0.46 & & 0 & 1 & 0.36 & 0.50 & 0.46 \\
\hline Masters & 0.24 & & 0 & 1 & 0.24 & 0.21 & 0.25 \\
\hline $\mathrm{PhD}$ & 0.30 & & 0 & 1 & 0.40 & 0.29 & 0.29 \\
\hline Carnegie rank: Research 1 & 0.47 & & 0 & 1 & 0.54 & 0.44 & 0.47 \\
\hline Carnegie rank: Research 2 & 0.09 & & 0 & 1 & 0.08 & 0.08 & 0.09 \\
\hline Carnegie rank: Doctorate granting & 0.12 & & 0 & 1 & 0.09 & 0.12 & 0.13 \\
\hline Carnegie rank: Compreh./Liberal arts & 0.19 & & 0 & 1 & 0.14 & 0.19 & 0.19 \\
\hline Carnegie rank: Other institution & 0.13 & & 0 & 1 & 0.14 & 0.17 & 0.12 \\
\hline Job related to degree & 2.53 & 0.66 & 1 & 3 & 2.52 & 2.53 & 2.53 \\
\hline Hours worked & 45.40 & 6.63 & 35 & $90 \S$ & 47.48 & 45.53 & 45.25 \\
\hline Professional meeting & 0.44 & & 0 & 1 & 0.44 & 0.43 & 0.44 \\
\hline Funding DoD/NASA & 0.13 & & 0 & 1 & 0.07 & 0.13 & 0.14 \\
\hline Funding NIH/NSF & 0.02 & & 0 & 1 & 0.06 & 0.05 & 0.01 \\
\hline Job tenure & 6.88 & 7.35 & 0 & $40 \S$ & 1.74 & 5.27 & 7.40 \\
\hline Basic research & 0.03 & & 0 & 1 & 0.04 & 0.05 & 0.03 \\
\hline Applied research & 0.20 & & 0 & 1 & 0.23 & 0.18 & 0.20 \\
\hline Development & 0.24 & & 0 & 1 & 0.23 & 0.21 & 0.24 \\
\hline Design & 0.19 & & 0 & 1 & 0.09 & 0.19 & 0.20 \\
\hline Computer apps. & 0.33 & & 0 & 1 & 0.41 & 0.37 & 0.32 \\
\hline Age & 40.73 & 10.01 & $22 \S$ & $70 \S$ & 38.37 & 41.03 & 40.85 \\
\hline Children & 0.93 & 1.14 & 0 & $8 \S$ & 0.94 & 0.87 & 0.94 \\
\hline Married & 0.75 & & 0 & 1 & 0.70 & 0.73 & 0.75 \\
\hline U.S. citizen & 0.85 & & 0 & 1 & 0.77 & 0.84 & 0.85 \\
\hline
\end{tabular}

Note: NSF confidentiality restrictions prohibit reporting descriptive statistics for cells below a certain number of cases. The sign "§" indicates that we report not the actual minimum/maximum but the closest value that satisfies the NSF requirement. Imp. $=$ Importance of. 
Table 3: Differences in Motives across Firm Types

\begin{tabular}{|c|c|c|c|c|c|c|c|c|c|c|}
\hline & $\begin{array}{c}1 \\
\text { ologit } \\
\text { Imp.Sec. }\end{array}$ & $\begin{array}{c}2 \\
\text { ologit } \\
\text { Imp.Sal. }\end{array}$ & $\begin{array}{c}3 \\
\text { ologit } \\
\text { Imp.Ind. }\end{array}$ & $\begin{array}{c}4 \\
\text { ologit } \\
\text { Imp.Resp. }\end{array}$ & $\begin{array}{c}5 \\
\text { ologit } \\
\text { Imp.Chal. }\end{array}$ & $\begin{array}{c}6 \\
\text { ologit } \\
\text { Imp.Sec. }\end{array}$ & $\begin{array}{c}7 \\
\text { ologit } \\
\text { Imp.Sal. }\end{array}$ & $\begin{array}{c}8 \\
\text { ologit } \\
\text { Imp.Ind. }\end{array}$ & $\begin{array}{c}9 \\
\text { ologit } \\
\text { Imp.Resp. }\end{array}$ & $\begin{array}{c}10 \\
\text { ologit } \\
\text { Imp.Chal. }\end{array}$ \\
\hline Startup & omitted & omitted & omitted & omitted & omitted & & & & & \\
\hline \multirow[t]{2}{*}{ Established small } & $1.547^{* *}$ & 1.068 & 0.986 & 0.989 & 0.933 & & & & & \\
\hline & {$[0.088]$} & {$[0.205]$} & {$[0.074]$} & {$[0.071]$} & {$[0.151]$} & & & & & \\
\hline \multirow[t]{2}{*}{ Established large } & $2.111^{* *}$ & $1.295^{*}$ & $0.836^{* *}$ & $0.855^{* *}$ & 0.794 & & & & & \\
\hline & {$[0.122]$} & {$[0.134]$} & {$[0.041]$} & [0.043] & {$[0.118]$} & & & & & \\
\hline \multirow[t]{2}{*}{ Firm age } & & & & & & $1.502^{* *}$ & 1.027 & 1.018 & 0.987 & 0.925 \\
\hline & & & & & & {$[0.107]$} & {$[0.202]$} & {$[0.076]$} & {$[0.075]$} & [0.152] \\
\hline Firm size: 1-10 & & & & & & omitted & omitted & omitted & omitted & omitted \\
\hline \multirow{2}{*}{ Firm size: $11-24$} & & & & & & 1.313 & 1.004 & $0.791 *$ & 0.963 & 0.892 \\
\hline & & & & & & [0.192] & {$[0.152]$} & {$[0.078]$} & [0.093] & {$[0.148]$} \\
\hline \multirow[t]{2}{*}{ Firm size: 25-99 } & & & & & & 1.296 & 1.292 & $0.761^{* *}$ & 1.004 & 1.028 \\
\hline & & & & & & [0.247] & {$[0.172]$} & {$[0.071]$} & {$[0.110]$} & [0.137] \\
\hline \multirow[t]{2}{*}{ Firm size: 100-499 } & & & & & & $1.443^{*}$ & $1.427^{*}$ & $0.675^{* *}$ & 0.909 & 0.91 \\
\hline & & & & & & {$[0.210]$} & {$[0.233]$} & {$[0.057]$} & {$[0.086]$} & {$[0.130]$} \\
\hline \multirow[t]{2}{*}{ Firm size: 500-999 } & & & & & & $1.899 * *$ & 1.319 & $0.734^{* *}$ & 0.93 & 0.857 \\
\hline & & & & & & {$[0.324]$} & {$[0.266]$} & {$[0.059]$} & {$[0.114]$} & {$[0.153]$} \\
\hline \multirow[t]{2}{*}{ Firm size: 1,000-4,999 } & & & & & & $1.607^{* *}$ & $1.483^{*}$ & $0.678^{* *}$ & 0.850 & 0.770 \\
\hline & & & & & & {$[0.231]$} & [0.229] & {$[0.083]$} & [0.095] & [0.107] \\
\hline \multirow[t]{2}{*}{ Firm size: 5,000-24,999 } & & & & & & $1.727^{* *}$ & 1.45 & $0.670^{* *}$ & $0.796^{*}$ & 0.821 \\
\hline & & & & & & {$[0.259]$} & [0.282] & {$[0.064]$} & {$[0.072]$} & [0.104] \\
\hline \multirow[t]{2}{*}{ Firm size: $25,000+$} & & & & & & $1.812^{* *}$ & 1.417 & $0.675^{* *}$ & 0.866 & 0.862 \\
\hline & & & & & & {$[0.249]$} & [0.292] & {$[0.071]$} & {$[0.090]$} & [0.121] \\
\hline \multirow[t]{2}{*}{ Masters degree } & $0.770^{* *}$ & 0.952 & 1.061 & $1.158^{*}$ & $1.254^{* *}$ & $0.766^{* *}$ & 0.949 & 1.063 & $1.159 *$ & $1.252^{* *}$ \\
\hline & {$[0.047]$} & {$[0.047]$} & {$[0.068]$} & {$[0.067]$} & {$[0.062]$} & {$[0.047]$} & [0.047] & {$[0.070]$} & {$[0.068]$} & {$[0.062]$} \\
\hline \multirow[t]{2}{*}{ PhD degree } & $0.603^{* *}$ & $0.684^{* *}$ & $1.289 * *$ & $1.332^{* *}$ & $1.830^{* *}$ & $0.597^{* *}$ & $0.684^{* *}$ & $1.290 * *$ & $1.335^{* *}$ & $1.828^{* *}$ \\
\hline & {$[0.032]$} & [0.037] & {$[0.098]$} & [0.087] & {$[0.112]$} & {$[0.031]$} & [0.039] & [0.099] & [0.089] & {$[0.115]$} \\
\hline Carnegie rank & incl. & incl. & incl. & incl. & incl. & incl. & incl. & incl. & incl. & incl. \\
\hline Degree field fe & incl. & incl. & incl. & incl. & incl. & incl. & incl. & incl. & incl. & incl. \\
\hline Demographic controls & incl. & incl. & incl. & incl. & incl. & incl. & incl. & incl. & incl. & incl. \\
\hline Industry fixed effects & incl. & incl. & incl. & incl. & incl. & incl. & incl. & incl. & incl. & incl. \\
\hline Observations & 10585 & 10585 & 10585 & 10585 & 10585 & 10585 & 10585 & 10585 & 10585 & 10585 \\
\hline $\mathrm{df}$ & 24 & 24 & 24 & 24 & 24 & 24 & 24 & 24 & 24 & 24 \\
\hline
\end{tabular}

Note: Ordered logit, odds ratios reported. Standard errors clustered by industry in brackets. $*=$ significant at $5 \%, * *=$ significant at $1 \%$. Omitted categories: Bachelors degree. Imp.Sec.=Importance of job security; Imp.Sal.=Importance of salary; Imp.Ind.=Importance of independence; Imp.Resp.=Importance of responsibility; Imp.Chal.=Importance of intellectual challenge. 
Table 4: Differences in Job Attributes

\begin{tabular}{|c|c|c|c|c|c|c|c|}
\hline & $\begin{array}{c}1 \\
\text { OLS } \\
\text { Ln salary }\end{array}$ & $\begin{array}{c}2 \\
\text { qreg(10) } \\
\text { Salary }\end{array}$ & $\begin{array}{c}3 \\
\text { qreg(50) } \\
\text { Salary }\end{array}$ & $\begin{array}{c}4 \\
\text { qreg(90) } \\
\text { Salary }\end{array}$ & $\begin{array}{c}5 \\
\text { OLS } \\
\text { Ln salary }\end{array}$ & $\begin{array}{c}6 \\
\text { nbreg } \\
\text { Non-R\&D }\end{array}$ & $\begin{array}{c}7 \\
\text { nbreg } \\
\text { Non-R\&D }\end{array}$ \\
\hline Established small & $\begin{array}{r}-0.093 * * \\
{[0.024]}\end{array}$ & $\begin{array}{r}-4.837^{* *} \\
{[1.329]}\end{array}$ & $\begin{array}{r}-6.286^{* *} \\
{[1.183]}\end{array}$ & $\begin{array}{r}-9.568 * * \\
{[2.571]}\end{array}$ & & $\begin{array}{r}0.995 \\
{[0.043]}\end{array}$ & \\
\hline Established large & $\begin{array}{r}0.025 \\
{[0.025]} \\
\end{array}$ & $\begin{array}{r}7.195^{* *} \\
{[1.121]} \\
\end{array}$ & $\begin{array}{r}0.928 \\
{[0.997]} \\
\end{array}$ & $\begin{array}{r}-7.294^{* *} \\
{[2.167]} \\
\end{array}$ & & $\begin{array}{r}0.827^{* *} \\
{[0.021]} \\
\end{array}$ & \\
\hline Firm age & & & & & $\begin{array}{r}-0.105^{* *} \\
{[0.028]}\end{array}$ & & $\begin{array}{r}1.022 \\
{[0.038]}\end{array}$ \\
\hline Firm size: $1-10$ & & & & & omitted & & omitted \\
\hline Firm size: $11-24$ & & & & & $\begin{array}{r}0.028 \\
{[0.034]}\end{array}$ & & $\begin{array}{r}0.906 \\
{[0.065]}\end{array}$ \\
\hline Firm size: 25-99 & & & & & $\begin{array}{l}0.082^{*} \\
{[0.038]}\end{array}$ & & $\begin{array}{r}0.832 * * \\
{[0.036]}\end{array}$ \\
\hline Firm size: 100-499 & & & & & $\begin{array}{r}0.117^{* *} \\
{[0.036]}\end{array}$ & & $\begin{array}{r}0.794^{* *} \\
{[0.030]}\end{array}$ \\
\hline Firm size: 500-999 & & & & & $\begin{array}{r}0.125^{* *} \\
{[0.029]}\end{array}$ & & $\begin{array}{r}0.725^{* *} \\
{[0.032]}\end{array}$ \\
\hline Firm size: $1,000-4,999$ & & & & & $\begin{array}{r}0.164 * * \\
{[0.027]}\end{array}$ & & $\begin{array}{r}0.692 * * \\
{[0.029]}\end{array}$ \\
\hline Firm size: 5,000-24,999 & & & & & $\begin{array}{r}0.180 * * \\
{[0.024]}\end{array}$ & & $\begin{array}{r}0.739 * * \\
{[0.033]}\end{array}$ \\
\hline Firm size: $25,000+$ & & & & & $\begin{array}{r}0.210 * * \\
{[0.026]}\end{array}$ & & $\begin{array}{r}0.709 * * \\
{[0.033]}\end{array}$ \\
\hline Masters degree & $\begin{array}{r}0.085^{* *} \\
{[0.008]}\end{array}$ & $\begin{array}{r}6.701 * * \\
{[0.670]}\end{array}$ & $\begin{array}{r}6.974 * * \\
{[0.583]}\end{array}$ & $\begin{array}{r}4.061^{* *} \\
{[1.259]}\end{array}$ & $\begin{array}{r}0.081^{* *} \\
{[0.007]}\end{array}$ & $\begin{array}{r}0.930 * * \\
{[0.021]}\end{array}$ & $\begin{array}{r}0.933^{* *} \\
{[0.021]}\end{array}$ \\
\hline PhD degree & $\begin{array}{r}0.256^{* *} \\
{[0.019]}\end{array}$ & $\begin{array}{r}19.620 * * \\
{[0.826]}\end{array}$ & $\begin{array}{r}21.336^{* *} \\
{[0.710]}\end{array}$ & $\begin{array}{r}24.702 * * \\
{[1.554]}\end{array}$ & $\begin{array}{r}0.250 * * \\
{[0.018]}\end{array}$ & $\begin{array}{r}0.832 * * \\
{[0.030]}\end{array}$ & $\begin{array}{r}0.835^{* *} \\
{[0.030]}\end{array}$ \\
\hline $\begin{array}{l}\text { Carnegie rank } \\
\text { Degree field fixed effects }\end{array}$ & $\begin{array}{l}\text { incl. } \\
\text { incl. }\end{array}$ & $\begin{array}{l}\text { incl. } \\
\text { incl. }\end{array}$ & $\begin{array}{l}\text { incl. } \\
\text { incl. }\end{array}$ & $\begin{array}{l}\text { incl. } \\
\text { incl. }\end{array}$ & $\begin{array}{l}\text { incl. } \\
\text { incl. }\end{array}$ & $\begin{array}{l}\text { incl. } \\
\text { incl. }\end{array}$ & $\begin{array}{l}\text { incl. } \\
\text { incl. }\end{array}$ \\
\hline Basic research & $\begin{array}{r}-0.096 * * \\
{[0.017]}\end{array}$ & $\begin{array}{r}-6.681^{* *} \\
{[1.484]}\end{array}$ & $\begin{array}{r}-6.392^{* *} \\
{[1.301]}\end{array}$ & $\begin{array}{r}-8.597^{* *} \\
{[2.817]}\end{array}$ & $\begin{array}{r}-0.094^{* *} \\
{[0.017]}\end{array}$ & $\begin{array}{r}0.827^{* *} \\
{[0.043]}\end{array}$ & $\begin{array}{r}0.828 * * \\
{[0.042]}\end{array}$ \\
\hline Development & $\begin{array}{r}-0.003 \\
{[0.010]}\end{array}$ & $\begin{array}{r}-0.331 \\
{[0.826]}\end{array}$ & $\begin{array}{r}-0.230 \\
{[0.714]}\end{array}$ & $\begin{array}{r}-0.808 \\
{[1.561]}\end{array}$ & $\begin{array}{r}-0.001 \\
{[0.010]}\end{array}$ & $\begin{array}{r}1.010 \\
{[0.028]}\end{array}$ & $\begin{array}{r}1.010 \\
{[0.028]}\end{array}$ \\
\hline Design & $\begin{array}{r}-0.025^{*} \\
{[0.011]}\end{array}$ & $\begin{array}{r}-0.621 \\
{[0.932]}\end{array}$ & $\begin{array}{c}-1.659 * \\
{[0.813]}\end{array}$ & $\begin{array}{c}-4.354 * \\
{[1.801]}\end{array}$ & $\begin{array}{c}-0.023^{*} \\
{[0.011]}\end{array}$ & $\begin{array}{r}0.933 \\
{[0.033]}\end{array}$ & $\begin{array}{r}0.933 \\
{[0.033]}\end{array}$ \\
\hline Computer applications & $\begin{array}{r}-0.042 * * \\
{[0.012]}\end{array}$ & $\begin{array}{l}-1.877^{*} \\
{[0.894]}\end{array}$ & $\begin{array}{r}-3.977^{* *} \\
{[0.770]}\end{array}$ & $\begin{array}{r}-5.967 * * \\
{[1.656]}\end{array}$ & $\begin{array}{r}-0.041^{* *} \\
{[0.011]}\end{array}$ & $\begin{array}{r}0.758 * * \\
{[0.025]}\end{array}$ & $\begin{array}{r}0.758 * * \\
{[0.025]}\end{array}$ \\
\hline Job related degree & $\begin{array}{r}0.037 * * \\
{[0.006]}\end{array}$ & $\begin{array}{r}3.068 * * \\
{[0.421]}\end{array}$ & $\begin{array}{r}1.844^{* *} \\
{[0.371]}\end{array}$ & $\begin{array}{r}3.452 * * \\
{[0.834]}\end{array}$ & $\begin{array}{r}0.039 * * \\
{[0.006]}\end{array}$ & $\begin{array}{c}1.026 * \\
{[0.012]}\end{array}$ & $\begin{array}{r}1.023^{*} \\
{[0.011]}\end{array}$ \\
\hline $\begin{array}{l}\text { Demographic controls } \\
\text { Industry fixed effects }\end{array}$ & $\begin{array}{l}\text { incl. } \\
\text { incl. }\end{array}$ & $\begin{array}{l}\text { incl. } \\
\text { incl. }\end{array}$ & $\begin{array}{l}\text { incl. } \\
\text { incl. }\end{array}$ & $\begin{array}{l}\text { incl. } \\
\text { incl. }\end{array}$ & $\begin{array}{l}\text { incl. } \\
\text { incl. }\end{array}$ & $\begin{array}{l}\text { incl. } \\
\text { incl. }\end{array}$ & $\begin{array}{l}\text { incl. } \\
\text { incl. }\end{array}$ \\
\hline Constant & $\begin{array}{c}9.879 * * \\
{[0.052]}\end{array}$ & $\begin{array}{r}-17.944^{* *} \\
{[5.507]}\end{array}$ & $\begin{array}{r}-12.078^{*} \\
{[4.743]}\end{array}$ & $\begin{array}{r}-3.008 \\
{[10.227]}\end{array}$ & $\begin{array}{c}9.829 * * \\
{[0.047]}\end{array}$ & & \\
\hline Observations & 10585 & 10585 & 10585 & 10585 & 10585 & 10585 & 10585 \\
\hline $\begin{array}{r}d f \\
\text { alphaest } \\
\text { R-squared }\end{array}$ & 0.368 & 68 & 68 & 68 & 0.376 & $\begin{array}{r}25 \\
0.203\end{array}$ & $\begin{array}{r}25 \\
0.2\end{array}$ \\
\hline
\end{tabular}

Note: Models 1 and 5 OLS, 2-4 quantile regression, 6-7 negative binomial (Incidence Rate Ratios reported). Standard errors in brackets (clustered in models $1,5-7)$. $*$ sig. at $5 \%, * *=$ sig. at $1 \%$. Omitted: Startup; Bachelors degree. Models 2-4 use salary in thousands. Non-R\&D=Number of non-R\&D work activities. 
Table 5: Differences in Innovative Performance

\begin{tabular}{|c|c|c|c|c|c|c|}
\hline & $\begin{array}{c}1 \\
\text { nbreg } \\
\text { Patents } \\
\end{array}$ & $\begin{array}{c}2 \\
\text { nbreg } \\
\text { Patents } \\
\end{array}$ & $\begin{array}{c}3 \\
\text { nbreg } \\
\text { Patents }\end{array}$ & $\begin{array}{c}4 \\
\text { nbreg } \\
\text { Patents } \\
\end{array}$ & $\begin{array}{c}5 \\
\text { nbreg } \\
\text { Patents } \\
\end{array}$ & $\begin{array}{c}6 \\
\text { nbreg } \\
\text { Patents } \\
\end{array}$ \\
\hline \multirow[t]{2}{*}{ Established small } & $0.481^{* *}$ & $0.531^{* *}$ & $0.553^{* *}$ & & & \\
\hline & {$[0.062]$} & {$[0.068]$} & {$[0.066]$} & & & \\
\hline \multirow[t]{2}{*}{ Established large } & $0.702 * *$ & $0.805^{*}$ & 0.843 & & & \\
\hline & {$[0.084]$} & [0.087] & {$[0.096]$} & & & \\
\hline \multirow[t]{2}{*}{ Importance of security } & & $0.773^{* *}$ & $0.784^{* *}$ & & $0.768^{* *}$ & $0.779 * *$ \\
\hline & & {$[0.038]$} & {$[0.039]$} & & [0.039] & [0.040] \\
\hline \multirow[t]{2}{*}{ Importance of salary } & & 1.053 & 1.073 & & 1.054 & 1.074 \\
\hline & & [0.064] & {$[0.064]$} & & {$[0.072]$} & {$[0.071]$} \\
\hline \multirow[t]{2}{*}{ Importance of independence } & & $1.147^{*}$ & $1.159 * *$ & & $1.136^{*}$ & $1.148^{*}$ \\
\hline & & [0.068] & {$[0.066]$} & & {$[0.068]$} & [0.066] \\
\hline \multirow[t]{2}{*}{ Importance of responsibility } & & 0.926 & 0.901 & & 0.940 & 0.915 \\
\hline & & {$[0.051]$} & {$[0.050]$} & & {$[0.058]$} & [0.057] \\
\hline \multirow[t]{2}{*}{ Importance of challenge } & & $1.443^{* *}$ & $1.417^{* *}$ & & $1.418^{* *}$ & $1.392 * *$ \\
\hline & & {$[0.097]$} & {$[0.096]$} & & [0.095] & [0.095] \\
\hline \multirow[t]{2}{*}{ Hours worked } & & & $1.019^{* *}$ & & & $1.019 * *$ \\
\hline & & & {$[0.003]$} & & & {$[0.003]$} \\
\hline \multirow[t]{2}{*}{ Firm age } & & & & $0.495^{* *}$ & $0.549 * *$ & $0.576^{* *}$ \\
\hline & & & & {$[0.068]$} & {$[0.077]$} & {$[0.075]$} \\
\hline Firm size: 1-10 & & & & omitted & omitted & omitted \\
\hline \multirow[t]{2}{*}{ Firm size: $11-24$} & & & & 0.700 & 0.755 & 0.748 \\
\hline & & & & [0.173] & {$[0.191]$} & [0.186] \\
\hline \multirow[t]{2}{*}{ Firm size: 25-99 } & & & & 0.742 & 0.74 & 0.721 \\
\hline & & & & {$[0.225]$} & {$[0.209]$} & [0.209] \\
\hline \multirow[t]{2}{*}{ Firm size: 100-499 } & & & & 0.745 & 0.794 & 0.781 \\
\hline & & & & [0.155] & {$[0.160]$} & [0.155] \\
\hline \multirow[t]{2}{*}{ Firm size: 500-999 } & & & & 0.942 & 0.961 & 0.934 \\
\hline & & & & {$[0.269]$} & {$[0.272]$} & [0.267] \\
\hline \multirow[t]{2}{*}{ Firm size: 1,000-4,999 } & & & & 0.994 & 1.064 & 1.060 \\
\hline & & & & {$[0.283]$} & {$[0.288]$} & [0.286] \\
\hline \multirow[t]{2}{*}{ Firm size: 5,000-24,999 } & & & & 1.142 & 1.211 & 1.205 \\
\hline & & & & {$[0.443]$} & {$[0.452]$} & [0.452] \\
\hline \multirow[t]{2}{*}{ Firm size: $25,000+$} & & & & 1.367 & 1.422 & 1.395 \\
\hline & & & & {$[0.483]$} & {$[0.476]$} & [0.459] \\
\hline Educational controls & incl. & incl. & incl. & incl. & incl. & incl. \\
\hline Work activity controls & incl. & incl. & incl. & incl. & incl. & incl. \\
\hline Demographic controls & incl. & incl. & incl. & incl. & incl. & incl. \\
\hline Industry fixed effects & incl. & incl. & incl. & incl. & incl. & incl. \\
\hline Observations & 10585 & 10585 & 10585 & 10585 & 10585 & 10585 \\
\hline$d f$ & 25 & 25 & 25 & 25 & 25 & 25 \\
\hline alphaest & 4.165 & 4.067 & 4.038 & 4.114 & 4.019 & 3.988 \\
\hline
\end{tabular}

Note: Negative binomial regression, Incidence Rate Ratios reported. Standard errors clustered by industry in brackets. ${ }^{*}=$ sig. at $5 \%,{ }^{*}=$ sig. at $1 \%$. Omitted categories: Startup. 
Table 6: Testing Mediation Using Products of Coefficients and Bootstrapping

\begin{tabular}{ll|rrr}
\hline Motive & Firm Type & Product of Coefficients & [95\% Confidence Interval] \\
\hline Job security & Established small & -0.00682 & -0.01233 & -0.00263 \\
& Established large & -0.01171 & -0.01864 & -0.00574 \\
Salary & All firm types & -0.01853 & -0.03057 & -0.00867 \\
& Established small & 0.00056 & -0.00087 & 0.00251 \\
& Established large & 0.00177 & -0.00018 & 0.00432 \\
Independence & All firm types & 0.00233 & -0.00048 & 0.00658 \\
& Established small & -0.00008 & -0.00172 & 0.00150 \\
Responsibility & All firm types & -0.00108 & -0.00306 & 0.00019 \\
& Established small & -0.00116 & -0.00456 & 0.00130 \\
& Established large & 0.00031 & -0.00088 & 0.00197 \\
& All firm types & 0.00081 & -0.00041 & 0.00278 \\
Challenge & Established small & 0.00112 & -0.00084 & 0.00452 \\
& Established large & -0.00033 & -0.00362 & 0.00302 \\
& All firm types & -0.00261 & -0.00567 & 0.00021 \\
All motives & Established small & -0.00294 & -0.00874 & 0.00287 \\
\hline & Established large & -0.00637 & -0.01285 & -0.00082 \\
& All firm types & -0.01281 & -0.02066 & -0.00583 \\
& & -0.01918 & -0.03287 & -0.00724 \\
\hline
\end{tabular}

Note: Based on seemingly unrelated OLS regressions of motives on firm types dummies and a regression of (Ln) patents on firm type dummies and motives, including controls. Confidence intervals based on bootstrapping with 5,000 repetitions. 
Figure 1: Profile of Employee Motives Across Firm Types

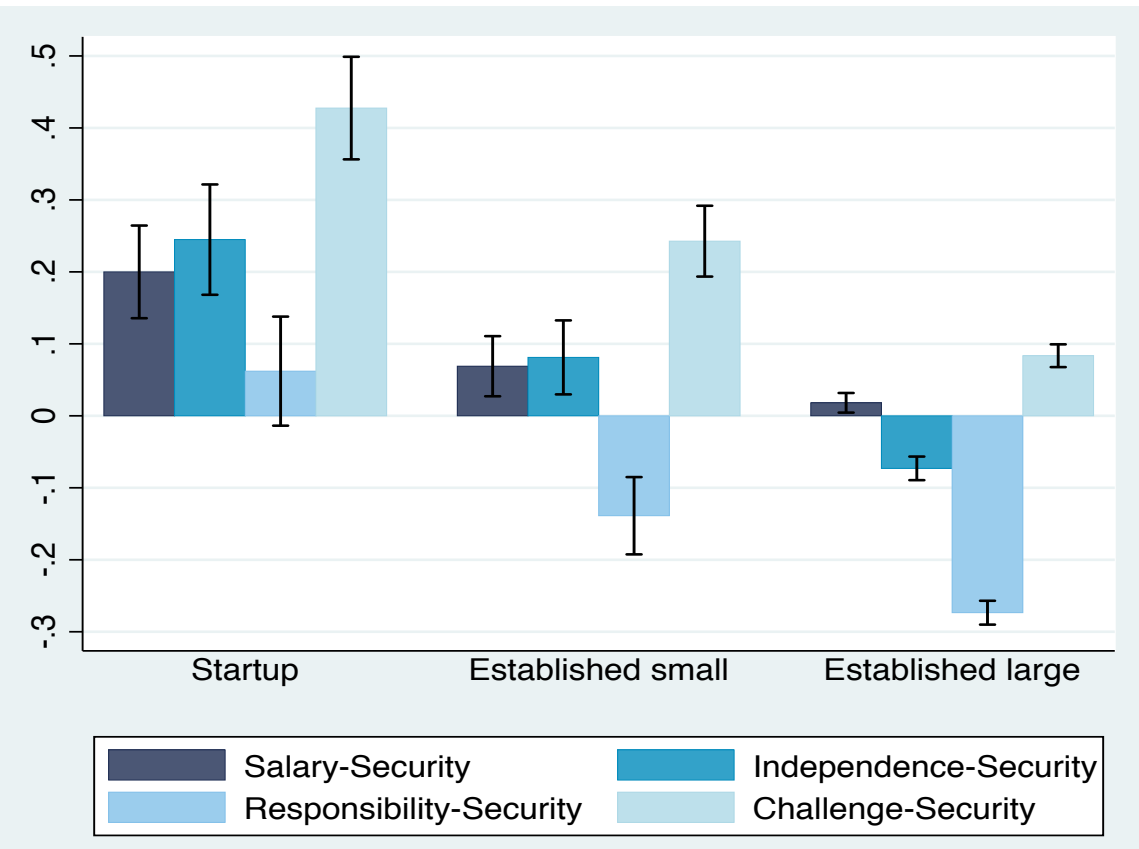

Note: Differences between salary, independence, responsibility and challenge motives on the one hand, and security motives on the other. Averaged across individuals by firm type, including $95 \%$ confidence intervals. 


\section{REFERENCES}

Acs, Z. J., \& Audretsch, D. B. 1990. Innovation and Small Firms. Cambridge, Mass.: MIT Press.

Agarwal, R., \& Audretsch, D. B. 2001. Does entry size matter? The impact of the life cycle and technology on firm survival. The Journal of Industrial Economics, 49(1): 21-43.

Agarwal, R., Campbell, B., Franco, A., \& Ganco, M. 2016. What do I take with me? The mediating effect of spin-out team size and tenure on the founder-firm performance relationship. Academy of Management Journal, 59(3): 1060-1087.

Agarwal, R., Ganco, M., \& Ziedonis, R. H. 2009. Reputations for toughness in patent enforcement: Implications for knowledge spillovers via inventor mobility. Strategic Management Journal, 30(13): 1349-1374.

Agarwal, R., \& Ohyama, A. 2013. Industry or academia, basic or applied? Career choices and earnings trajectories of scientists. Management Science, 59(4): 950-970.

Agrawal, A. K., Cockburn, I. M., Galasso, A., \& Oettl, A. 2014. Why are some regions more innovative than others? The role of small firms in the presence of large labs. Journal of Urban Economics, 81: $149-165$.

Allen, T. J., \& Katz, R. 1992. Age, education and the technical ladder. IEEE Transactions on Engineering Management, 39(3): 237-245.

Amabile, T. 1996. Creativity in Context. Boulder, Colo.: Westview Press.

Amabile, T. M., \& Gryskiewicz, S. S. 1987. Creativity in the R\&D Laboratory: Center for Creative Leadership.

Amabile, T. M., Hill, K. G., Hennessey, B. A., \& Tighe, E. M. 1994. The work preference inventory Assessing intrinsic and extrinsic motivational orientations. Journal of Personality and Social Psychology, 66(5): 950-967.

Amit, R., MacCrimmon, K. R., Zietsma, C., \& Oesch, J. M. 2001. Does money matter?: Wealth attainment as the motive for initiating growth-oriented technology ventures. Journal of Business Venturing, 16(2): 119-143.

Arora, A., Gambardella, A., Magazzini, L., \& Pammolli, F. 2009. A breath of fresh air? Firm type, scale, scope, and selection effects in drug development. Management Science, 55(10): 1638-1653.

Arora, A., \& Nandkumar, A. 2011. Cash-out or flameout! Opportunity cost and entrepreneurial strategy: Theory and evidence from the information security industry. Management Science, 57(10): 1844-1860.

Astebro, T., \& Thompson, P. 2011. Entrepreneurs, Jacks of all trades or Hobos? Research Policy, 40(5): 637-649.

Baron, J. N., Hannan, M. T., \& Burton, M. D. 2001. Labor pains: change in organizational models and employee turnover in young, high-tech firms. American Journal of Sociology, 106(4): 960-1012.

Baron, R. M., \& Kenny, D. A. 1986. The moderator-mediator variable distinction in social psychological research. Journal of Personality and Social Psychology, 51(6): 1173-1182.

Becker, G. S. 1973. A theory of marriage: Part I. The Journal of Political Economy: 813-846.

Beckman, C. M., \& Burton, M. D. 2008. Founding the future: Path dependence in the evolution of top management teams from founding to IPO. Organization Science, 19(1): 3-24.

Belenzon, S., \& Pattaconi, A. 2012. Performance, firm size, and the "basicness" of research, Working Paper.

Bengtsson, O., \& Hand, J. 2013. Employee compensation in entrepreneurial companies. Journal of Economics \& Management Strategy, 22(2): 312-340.

Benz, M., \& Frey, B. S. 2008. Being independent is a great thing: Subjective evaluations of selfemployment and hierarchy. Economica, 75(298): 362-383.

Besley, T., \& Ghatak, M. 2005. Competition and incentives with motivated agents. American Economic Review, 95(3): 616-636.

Bode, C., Singh, J., \& Rogan, M. 2015. Corporate social initiatives and employee retention. Organization Science, 26(6): 1702-1720. 
Braguinsky, S., Klepper, S., \& Ohyama, A. 2012. High-tech entrepreneurship. Journal of Law and Economics, 55(4): 869-900.

Brown, C., \& Medoff, J. 1989. The employer size wage effect. Journal of Political Economy, 97(5): 1027-1059.

Brown, C., \& Medoff, J. L. 2003. Firm age and wages. Journal of Labor Economics, 21(3): 677-697.

Burton, M. D. 2001. The company they keep: Founders' models for organizing new firms. In C. Schoonhoven, \& E. Romanelli (Eds.), The Entrepreneurship Dynamic: Origins of Entrepreneurship and the Evolution of Industries: 13-39: Stanford University Press.

Burton, M. D., Dahl, M., \& Sorenson, O. 2016. Do startups create good jobs?, Working Paper.

Byron, K., \& Khazanchi, S. 2012. Rewards and creative performance: A meta-analytic test of theoretically derived hypotheses. Psychological Bulletin, 138(4): 809-830.

Cable, D. M., \& Edwards, J. R. 2004. Complementary and supplementary fit: A theoretical and empirical integration. Journal of Applied Psychology, 89(5): 822-834.

Campbell, B. A., Ganco, M., Franco, A. M., \& Agarwal, R. 2012. Who leaves, where to, and why worry? employee mobility, entrepreneurship and effects on source firm performance. Strategic Management Journal, 33: 65-87.

Carnahan, S., Campbell, B., Agarwal, R., \& Franco, A. 2011. Brids of a feather flock together: Two sided incomplete information and human capital composition over the firm lifecycle, DRUID Conference.

Carroll, G., \& Hannan, M. T. 2000. The Demography of Corporations and Industries. Princeton, N.J.: Princeton University Press.

Chatman, J. A. 1991. Matching people and organizations: Selection and socialization in public accounting firms. Administrative Science Quarterly, 36(3): 459-484.

Chen, P.-L., Williams, C., \& Agarwal, R. 2012. Growing pains: Pre-entry experience and the challenge of transition to incumbency. Strategic Management Journal, 33(3): 252-276.

Coff, R., \& Kryscynski, D. 2011. Drilling for micro-foundations of human capital-based competitive advantages. Journal of Management, 37(5): 1429-1443.

Cohen, W. M. 2010. Fifty years of empirical studies of innovative activity and performance. Handbook of the Economics of Innovation, 1: 129-213.

Cohen, W. M., Nelson, R. R., \& Walsh, J. P. 2000. Protecting their intellectual assets: Appropriability conditions and why U.S. manufacturing firms patent (or not), NBER Working Paper \#7552.

Cohen, W. M., \& Sauermann, H. 2007. Schumpeter's Prophecy and Individual Incentives as a Driver of Innovation. In F. Malerba, \& S. Brusoni (Eds.), Perspectives on Innovation: 73-104.

Cooper, A. 1964. R\&D is more efficient in small companies. Harvard Business Review, 42(3): 75-83.

Cooper, A. 1966. Small companies can pioneer new products. Harvard Business Review, (Sept.-Oct.): 162-179.

Criscuolo, P., Nicolaou, N., \& Salter, A. 2012. The elixir (or burden) of youth? Exploring differences in innovation between start-ups and established firms. Research Policy, 41(2): 319-333.

Deci, E. L., Koestner, R., \& Ryan, R. M. 1999. A meta-analytic review of experiments examining the effects of extrinsic rewards on intrinsic motivation. Psychological Bulletin, 125(6): 627-668.

Ding, W. 2009. The impact of founder professional education background on the adoption of open science by for-profit biotechology firms, Working Paper.

Dunbar, K. 1995. How scientists really reason: Scientific reasoning in real-world laboratories. In R. J. Sternberg, \& J. E. Davidson (Eds.), The Nature of Insight: 365-395. Cambridge, MA: MIT Press.

Eesley, C. E., \& Roberts, E. B. 2012. Are you experienced or are you talented?: When does innate talent versus experience explain entrepreneurial performance? Strategic Entrepreneurship Journal, 6(3): 207-219.

Eisenberger, R., \& Shanock, L. 2003. Rewards, intrinsic motivation, and creativity: A case study of conceptual and methodological isolation. Creativity Research Journal, 15: 121-130. 
Elfenbein, D. W., Hamilton, B. H., \& Zenger, T. R. 2010. The small firm effect and the entrepreneurial spawning of scientists and engineers. Management Science, 56(4): 659-681.

Evans, D. S., \& Leighton, L. S. 1989. Why do smaller firms pay less? The Journal of Human Resources, 24(2): 299-318.

Fleming, L. 2001. Recombinant uncertainty in technological search. Management Science, 47(1): 117132.

Freiberger, P., \& Swaine, M. 1984. Fire in the Valley: The Making of the Personal Computer. Berkeley, Calif.: Osborne/McGraw-Hill.

Frey, B. S., \& Jegen, R. 2001. Motivation crowding theory. Journal of Economic Surveys, 15(5): 589611.

Friedman, R. S., \& Foerster, J. 2005. Effects of motivational cues on perceptual asymmetry: Implications for creativity and analytical problem solving. Journal of Personality and Social Psychology, 88: 263-275.

Gambardella, A., Panico, C., \& Valentini, G. 2015. Strategic incentives to human capital. Strategic Management Journal, 36(1): 37-52.

Ganco, M., Ziedonis, R. H., \& Agarwal, R. 2014. More stars stay, but the brightest ones still leave: Job hopping in the shadow of patent enforcement. Strategic Management Journal.

Gans, J. S., Hsu, D. H., \& Stern, S. 2002. When does start-up innovation spur the gale of creative destruction? The RAND Journal of Economics, 33(4): 571-586.

Halaby, C. N. 2003. Where job values come from: family and schooling background, cognitive ability, and gender. American Sociological Review: 251-278.

Haltiwanger, J., Jarmin, R. S., \& Miranda, J. 2013. Who creates jobs? Small versus large versus young. Review of Economics and Statistics, 95(2): 347-361.

Hamilton, B. H. 2000. Does entrepreneurship pay? An empirical analysis of the returns to selfemployment. Journal of Political Economy, 108(3): 604-631.

Hamilton, B. H., Papageorge, N. W., \& Pande, N. 2014. The right stuff? Personality and entrepreneurship, Working Paper.

Hayes, A. F. 2009. Beyond Baron and Kenny: Statistical mediation analysis in the new millennium. Communication Monographs, 76(4): 408-420.

Hsu, D., Roberts, E., \& Eesley, C. 2007. Entrepreneurs from technology-based universities: Evidence from MIT. Research Policy, 36(5): 768-788.

Hsu, D. H., \& Ziedonis, R. H. 2013. Resources as dual sources of advantage: Implications for valuing entrepreneurial-firm patents. Strategic Management Journal, 34(7): 761-781.

Hwang, H., Mortensen, D. T., \& Reed, W. R. 1998. Hedonic wages and labor market search. Journal of Labor Economics, 16(4): 815-847.

Idson, T. L. 1990. Establishment size, job-satisfaction and the structure of work. Applied Economics, 22(8): 1007-1018.

Idson, T. L., \& Feaster, D. J. 1990. A selectivity model of employer-size wage differentials. Journal of Labor Economics, 8(1): 99-122.

Jovanovic, B. 1982. Selection and the evolution of industry. Econometrica, 50(3): 649-670.

Killingsworth, M. 1987. Heterogeneous preferences, compensating wage differentials, and comparable worth. Quarterly Journal of Economics, 102(4): 727-742.

Kim, D. 2016. Is there a startup wage premium? Evidence from MIT graduates, Working Paper.

Kornhauser, W. 1962. Scientists in Industry: Conflict and Accommodation. Berkeley: University of California Press.

Kryscynski, D., Coff, R., \& Campbell, B. 2014. Utility Players and Utility Functions: Value Creation and Capture of ex ante Worker-Firm Complementarities, Working Paper.

Lacetera, N. 2009. Different missions and commitment power in R\&D organizations: Theory and evidence on industry-university alliances. Organization Science, 20(3): 565-582.

Lazear, E. P. 2005. Entrepreneurship. Journal of Labor Economics, 23(4): 649-680.

Lerner, J. 2009. Boulevard of Broken Dreams: Princeton Univ Press. 
Levinthal, D. A., \& March, J. G. 1993. The myopia of learning. Strategic Management Journal, 14(S2): 95-112.

Lowe, R. A., \& Ziedonis, A. A. 2006. Overoptimism and the performance of entrepreneurial firms. Management Science, 52(2): 173-186.

Moorman, R. H., \& Podsakoff, P. M. 1992. A metaanalytic review and empirical test of the potential confounding effects of social desirability response sets in organizational behavior research. Journal of Occupational and Organizational Psychology, 65(2): 131-149.

Morton, F. M. S., \& Podolny, J. M. 2002. Love or money? The effects of owner motivation in the California wine industry. Journal of Industrial Economics, 50(4): 431-456.

Neff, G. 2012. Venture Labor: Work and the Burden of Risk in Innovative Industries. Cambridge, MA: MIT Press.

O'Reilly, C. 1989. Corporations, culture, and commitment: Motivation and social control in organizations. California Management Review, 31(4): 9-25.

Ohyama, A. 2015. Entrepreneurship and Job-relatedness of Human Capital. Economica, 82(328): 740768.

Oi, W. Y., \& Idson, T. L. 1999. Firm size and wages. In O. Ashenfelter, \& D. Card (Eds.), Handbook of Labor Economics, Vol. 3B: 2165-2214. Amsterdam: Elsevier.

Ouimet, P., \& Zarutskie, R. 2014. Who works for startups? The relation between firm age, employee age, and growth. Journal of Financial Economics, 112(3): 386-407.

Podsakoff, P. M., MacKenzie, J. Y., \& Lee, J. Y. 2003. Common methods bias in behavioral research: A critical review and recommended remedies. Journal of Applied Psychology, 88(5): 879-903.

Preacher, K. J., \& Hayes, A. F. 2008. Asymptotic and resampling strategies for assessing and comparing indirect effects in multiple mediator models. Behavior Research Methods, 40(3): 879-891.

Prusa, T. J., \& Schmitz, J. A. 1991. Are new firms an important source of innovation? Evidence from the PC software industry. Economics Letters, 35(3): 339-342.

Ritti, R. 1968. Work goals of scientists and engineers. Industrial Relations, 7(2): 118-131.

Roach, M., \& Sauermann, H. 2010. A taste for science? PhD scientists' academic orientation and selfselection into research careers in industry. Research Policy, 39(3): 422-434.

Roach, M., \& Sauermann, H. 2015. Founder or Joiner? The role of preferences and context in shaping different entrepreneurial interests. Management Science, 61(9): 2160-2184.

Roberts, E. B. 1991. Entrepreneurs in High Technology: Lessons from MIT and beyond. New York: Oxford University Press.

Rosen, S. 1986. The theory of equalizing differences. In O. Ashenfelter, \& R. Layard (Eds.), Handbook of Labor Economics: 641-692: North-Holland.

Rosenberg, N. 1990. Why do firms do basic research (with their own money)? Research Policy, 19: 165174.

Rothaermel, F. T., \& Hess, A. M. 2007. Building dynamic capabilities: innovation driven by individual, firm, and network level effects. Organization Science, 18: 898-921.

Sauermann, H., \& Cohen, W. 2010. What makes them tick? Employee motives and firm innovation. Management Science, 56(12): 2134-2153.

Sauermann, H., Cohen, W. M., \& Stephan, P. E. 2016. Doing well or doing good? The motives, incentives, and commercial activities of academic scientists and engineers, Working Paper.

Sauermann, H., \& Roach, M. 2014. Not all scientists pay to be scientists: PhDs' preferences for publishing in industrial employment. Research Policy, 43(1): 32-47.

Sauermann, H., \& Stephan, P. 2013. Conflicting logics? A multidimensional view of industrial and academic science. Organization Science, 24(3): 889-909.

Schramm, C. J. 2006. The Entrepreneurial Imperative: How America's Economic Miracle Will Reshape the World: Collins New York.

Schumpeter, J. A. 1942. Capitalism, Socialism and Democracy: Harper \& Brothers.

Selby, J., \& Mayer, K. 2013. Startup firm acquisition as a human resource strategy for innovation: The Acqhire phenomenon, Working Paper. 
Shalley, C. E., Zhou, J., \& Oldham, G. R. 2004. The effects of personal and contextual characteristics on creativity: Where should we go from here? Journal of Management, 30(6): 933-958.

Shane, S., Locke, E. A., \& Collins, C. J. 2003. Entrepreneurial motivation. Human Resource Management Review, 13: 257-279.

Simonton, D. K. 2003. Scientific creativity as constrained stochastic behavior: the integration of product, person, and process perspectives. Psychological Bulletin, 129(4): 475-494.

Sorensen, J. B. 2007. Bureaucracy and entrepreneurship: Workplace effects on entrepreneurial entry. Administrative Science Quarterly, 52(3): 387-412.

Stenard, B. S., \& Sauermann, H. 2016. Educational mismatch, work outcomes, and entry into entrepreneurship. Organization Science, 27(4): 801-824.

Stern, S. 2004. Do scientists pay to be scientists? Management Science, 50(6): 835-853.

Toole, A. A., \& Czarnitzki, D. 2009. Exploring the relationship between scientist human capital and firm performance: The case of biomedical academic entrepreneurs in the SBIR program. Management Science, 55(1): 101-114.

Vascellaro, J., \& Morrison, S. 2008. Google gears down for tougher times, Wall Street Journal: A1.

Wang, J., Veugelers, R., \& Stephan, P. 2016. Bias against novelty in science: A cautionary tale for users of bibliometric indicators, NBER Working Paper \#22180.

Younge, K. A., Tong, T. W., \& Fleming, L. 2015. How anticipated employee mobility affects acquisition likelihood: Evidence from a natural experiment. Strategic Management Journal, 36(5): 686-708.

Zenger, T. R. 1994. Explaining organizational diseconomies of scale in R\&D: Agency problems and the allocation of engineering talent, ideas, and effort by firm size. Management Science, 40(6): 708729.

Zenger, T. R., \& Lazzarini, S. G. 2004. Compensating for innovation: Do small firms offer high-powered incentives that lure talent and motivate effort? Managerial and Decision Economics, 25: 329345. 


\section{SUPPORTING INFORMATION}

Table S1: Potential Changes in Motives over Time

\begin{tabular}{|c|c|c|c|c|c|c|c|c|c|c|}
\hline & $\begin{array}{c}1 \\
\text { ologit } \\
\text { Imp.Sec. } \\
\end{array}$ & $\begin{array}{c}2 \\
\text { ologit } \\
\text { Imp.Sal. }\end{array}$ & $\begin{array}{c}3 \\
\text { ologit } \\
\text { Imp.Ind. }\end{array}$ & $\begin{array}{c}4 \\
\text { ologit } \\
\text { Imp.Resp. }\end{array}$ & $\begin{array}{c}5 \\
\text { ologit } \\
\text { Imp.Chal. } \\
\end{array}$ & $\begin{array}{c}6 \\
\text { ologit } \\
\text { Imp.Sec. }\end{array}$ & $\begin{array}{c}7 \\
\text { ologit } \\
\text { Imp.Sal. }\end{array}$ & $\begin{array}{c}8 \\
\text { ologit } \\
\text { Imp.Ind. }\end{array}$ & $\begin{array}{c}9 \\
\text { ologit } \\
\text { Imp.Resp. }\end{array}$ & $\begin{array}{c}10 \\
\text { ologit } \\
\text { Imp.Chal. }\end{array}$ \\
\hline \multirow[t]{2}{*}{ Job tenure } & 0.981 & 1.006 & 1.025 & 0.992 & 0.984 & $1.013 * *$ & 0.998 & $1.006^{*}$ & 0.998 & $0.990 * *$ \\
\hline & {$[0.061]$} & {$[0.084]$} & {$[0.056]$} & {$[0.078]$} & {$[0.074]$} & [0.005] & {$[0.004]$} & [0.003] & {$[0.004]$} & [0.003] \\
\hline \multirow[t]{2}{*}{ Masters degree } & 0.649 & 0.746 & 0.803 & 1.163 & 0.63 & $0.793 * *$ & 0.935 & 1.049 & 1.112 & $1.229 * *$ \\
\hline & {$[0.222]$} & [0.189] & {$[0.235]$} & [0.369] & {$[0.167]$} & {$[0.050]$} & [0.047] & {$[0.087]$} & {$[0.081]$} & {$[0.068]$} \\
\hline \multirow[t]{2}{*}{ PhD degree } & 0.468 & $0.502^{*}$ & 1.143 & 1.056 & 1.199 & $0.667^{* *}$ & $0.698 * *$ & $1.241^{*}$ & $1.236 * *$ & $1.680 * *$ \\
\hline & [0.191] & [0.149] & {$[0.536]$} & {$[0.347]$} & {$[0.437]$} & {$[0.039]$} & {$[0.050]$} & {$[0.134]$} & {$[0.091]$} & [0.114] \\
\hline Industry fixed effects & incl. & incl. & incl. & incl. & incl. & incl. & incl. & incl. & incl. & incl. \\
\hline Educational controls & incl. & incl. & incl. & incl. & incl. & incl. & incl. & incl. & incl. & incl. \\
\hline Field fixed effects & incl. & incl. & incl. & incl. & incl. & incl. & incl. & incl. & incl. & incl. \\
\hline Demographic controls & incl. & incl. & incl. & incl. & incl. & incl. & incl. & incl. & incl. & incl. \\
\hline Work activity controls & incl. & incl. & incl. & incl. & incl. & incl. & incl. & incl. & incl. & incl. \\
\hline Observations & 580 & 580 & 580 & 580 & 580 & 8946 & 8946 & 8946 & 8946 & 8946 \\
\hline$d f$ & 22 & 22 & 22 & 22 & 22 & 24 & 24 & 24 & 24 & 24 \\
\hline
\end{tabular}

Note: Ordered logit, odds ratios reported. Standard errors clustered by industry in brackets. $*=$ sig. at $5 \%$, **=sig. at $1 \%$. Omitted categories: Bachelors degree. Imp.Sal.=Importance of salary; Imp.Ind.=Importance of independence; Imp.Resp.=Importance of responsibility; Imp.Chal.=Importance of intellectual challenge. 
Table S2: Auxiliary Analyses of Performance

\begin{tabular}{|c|c|c|c|c|c|c|c|c|c|c|c|c|}
\hline & \multirow{2}{*}{$\begin{array}{c}\text { If Patents<2 } \\
1 \\
\text { logit } \\
\text { Patents }\end{array}$} & \multicolumn{5}{|c|}{ If Patents $>0$} & \multicolumn{2}{|c|}{ If Patents $<21$} & \multicolumn{2}{|c|}{ Full sample } & \multicolumn{2}{|c|}{ High startup share } \\
\hline & & $\begin{array}{c}2 \\
\text { qreg(30) } \\
\text { Patents }\end{array}$ & $\begin{array}{c}3 \\
\text { qreg(50) } \\
\text { Patents }\end{array}$ & $\begin{array}{c}4 \\
\text { qreg(70) } \\
\text { Patents } \\
\end{array}$ & $\begin{array}{c}5 \\
\text { qreg(80) } \\
\text { Patents }\end{array}$ & $\begin{array}{c}6 \\
\text { qreg(90) } \\
\text { Patents } \\
\end{array}$ & $\begin{array}{c}7 \\
\text { nbreg } \\
\text { Patents } \\
\end{array}$ & $\begin{array}{c}8 \\
\text { nbreg } \\
\text { Patents }\end{array}$ & $\begin{array}{c}9 \\
\text { nbreg } \\
\text { Patents }\end{array}$ & $\begin{array}{c}10 \\
\text { nbreg } \\
\text { Patents }\end{array}$ & $\begin{array}{c}11 \\
\text { nbreg } \\
\text { Patents }\end{array}$ & $\begin{array}{c}12 \\
\text { nbreg } \\
\text { Patents }\end{array}$ \\
\hline Established small & $\begin{array}{r}0.633^{* *} \\
{[0.104]}\end{array}$ & $\begin{array}{r}-0.078 \\
{[0.240]}\end{array}$ & $\begin{array}{r}-0.16 \\
{[0.393]}\end{array}$ & $\begin{array}{r}-0.649 \\
{[0.840]}\end{array}$ & $\begin{array}{c}-1.427^{*} \\
{[0.689]}\end{array}$ & $\begin{array}{r}-1.821 \\
{[1.254]}\end{array}$ & $\begin{array}{r}0.477^{* *} \\
{[0.068]}\end{array}$ & $\begin{array}{r}0.505^{* *} \\
{[0.067]}\end{array}$ & $\begin{array}{r}0.518^{* *} \\
{[0.066]}\end{array}$ & $\begin{array}{r}0.549^{* *} \\
{[0.067]}\end{array}$ & $\begin{array}{r}0.565^{* *} \\
{[0.082]}\end{array}$ & $\begin{array}{r}0.616^{* *} \\
{[0.103]}\end{array}$ \\
\hline Established large & $\begin{array}{r}0.862 \\
{[0.123]} \\
\end{array}$ & $\begin{array}{r}-0.091 \\
{[0.186]} \\
\end{array}$ & $\begin{array}{r}0.152 \\
{[0.303]} \\
\end{array}$ & $\begin{array}{r}-0.328 \\
{[0.638]} \\
\end{array}$ & $\begin{array}{r}-0.571 \\
{[0.521]} \\
\end{array}$ & $\begin{array}{r}0.193 \\
{[0.981]} \\
\end{array}$ & $\begin{array}{r}0.717^{* *} \\
{[0.069]} \\
\end{array}$ & $\begin{array}{r}0.788^{*} \\
{[0.075]}\end{array}$ & $\begin{array}{r}0.711^{* *} \\
{[0.086]} \\
\end{array}$ & $\begin{array}{r}0.778^{*} \\
{[0.091]}\end{array}$ & $\begin{array}{r}0.713^{* *} \\
{[0.091]} \\
\end{array}$ & $\begin{array}{r}0.829 \\
{[0.093]} \\
\end{array}$ \\
\hline Importance security & $\begin{array}{r}0.879 \\
{[0.065]}\end{array}$ & $\begin{array}{r}-0.097 \\
{[0.077]}\end{array}$ & $\begin{array}{r}-0.146 \\
{[0.130]}\end{array}$ & $\begin{array}{r}-0.297 \\
{[0.277]}\end{array}$ & $\begin{array}{l}-0.479^{*} \\
{[0.226]}\end{array}$ & $\begin{array}{r}-1.329^{* *} \\
{[0.432]}\end{array}$ & & $\begin{array}{r}0.798^{* *} \\
{[0.043]}\end{array}$ & & $\begin{array}{r}0.815^{* *} \\
{[0.045]}\end{array}$ & & $\begin{array}{r}0.710^{* *} \\
{[0.046]}\end{array}$ \\
\hline Importance salary & $\begin{array}{r}0.872 \\
{[0.062]}\end{array}$ & $\begin{array}{r}0.098 \\
{[0.085]}\end{array}$ & $\begin{array}{r}0.213 \\
{[0.145]}\end{array}$ & $\begin{array}{r}0.37 \\
{[0.319]}\end{array}$ & $\begin{array}{c}0.531^{*} \\
{[0.262]}\end{array}$ & $\begin{array}{r}0.645 \\
{[0.516]}\end{array}$ & & $\begin{array}{r}1.037 \\
{[0.043]}\end{array}$ & & $\begin{array}{r}1.046 \\
{[0.060]}\end{array}$ & & $\begin{array}{c}1.111^{*} \\
{[0.058]}\end{array}$ \\
\hline Importance independence & $\begin{array}{c}0.877^{*} \\
{[0.057]}\end{array}$ & $\begin{array}{c}0.174 * \\
{[0.086]}\end{array}$ & $\begin{array}{c}0.364^{*} \\
{[0.147]}\end{array}$ & $\begin{array}{r}0.568 \\
{[0.313]}\end{array}$ & $\begin{array}{r}0.873^{* *} \\
{[0.253]}\end{array}$ & $\begin{array}{r}0.797 \\
{[0.464]}\end{array}$ & & $\begin{array}{c}1.105^{*} \\
{[0.051]}\end{array}$ & & $\begin{array}{r}1.108 \\
{[0.066]}\end{array}$ & & $\begin{array}{r}1.284^{* *} \\
{[0.046]}\end{array}$ \\
\hline Importance responsibility & $\begin{array}{r}1.003 \\
{[0.049]}\end{array}$ & $\begin{array}{r}-0.047 \\
{[0.081]}\end{array}$ & $\begin{array}{r}-0.176 \\
{[0.138]}\end{array}$ & $\begin{array}{r}-0.343 \\
{[0.302]}\end{array}$ & $\begin{array}{r}-0.345 \\
{[0.237]}\end{array}$ & $\begin{array}{r}-0.34 \\
{[0.442]}\end{array}$ & & $\begin{array}{c}0.902^{*} \\
{[0.040]}\end{array}$ & & $\begin{array}{r}0.916 \\
{[0.058]}\end{array}$ & & $\begin{array}{r}0.949 \\
{[0.058]}\end{array}$ \\
\hline Importance challenge & $\begin{array}{r}1.125 \\
{[0.100]} \\
\end{array}$ & $\begin{array}{r}0.075 \\
{[0.108]} \\
\end{array}$ & $\begin{array}{r}0.171 \\
{[0.176]} \\
\end{array}$ & $\begin{array}{r}0.533 \\
{[0.368]} \\
\end{array}$ & $\begin{array}{c}0.609 * \\
{[0.292]}\end{array}$ & $\begin{array}{r}1.402^{* *} \\
{[0.520]} \\
\end{array}$ & & $\begin{array}{r}1.423^{* *} \\
{[0.095]} \\
\end{array}$ & & $\begin{array}{r}1.384^{* *} \\
{[0.093]} \\
\end{array}$ & & $\begin{array}{r}1.559 * * \\
{[0.147]} \\
\end{array}$ \\
\hline $\begin{array}{l}\text { Ln Salary } \\
\text { Non-R\&D activities }\end{array}$ & & & & & & & & & $\begin{array}{r}4.245^{* *} \\
{[0.590]} \\
0.985 \\
{[0.024]} \\
\end{array}$ & $\begin{array}{r}3.939 * * \\
{[0.524]} \\
0.988 \\
{[0.028]} \\
\end{array}$ & & \\
\hline Master & $\begin{array}{r}1.289 \\
{[0.192]}\end{array}$ & $\begin{array}{r}0.173 \\
{[0.154]}\end{array}$ & $\begin{array}{r}0.064 \\
{[0.251]}\end{array}$ & $\begin{array}{r}-0.178 \\
{[0.539]}\end{array}$ & $\begin{array}{r}-0.259 \\
{[0.428]}\end{array}$ & $\begin{array}{r}-0.601 \\
{[0.761]}\end{array}$ & $\begin{array}{r}1.496^{* *} \\
{[0.088]}\end{array}$ & $\begin{array}{r}1.468^{* *} \\
{[0.077]}\end{array}$ & $\begin{array}{r}1.444^{* *} \\
{[0.094]}\end{array}$ & $\begin{array}{r}1.420^{* *} \\
{[0.084]}\end{array}$ & $\begin{array}{r}1.573^{* *} \\
{[0.117]}\end{array}$ & $\begin{array}{r}1.545^{* *} \\
{[0.083]}\end{array}$ \\
\hline $\mathrm{PhD}$ degree & $\begin{array}{r}2.618^{* *} \\
{[0.316]}\end{array}$ & $\begin{array}{r}0.492^{* *} \\
{[0.150]}\end{array}$ & $\begin{array}{r}0.818^{* *} \\
{[0.244]}\end{array}$ & $\begin{array}{l}1.196^{*} \\
{[0.519]}\end{array}$ & $\begin{array}{r}2.343^{* *} \\
{[0.413]}\end{array}$ & $\begin{array}{r}3.361^{* *} \\
{[0.743]}\end{array}$ & $\begin{array}{r}3.847^{* *} \\
{[0.505]}\end{array}$ & $\begin{array}{r}3.714^{* *} \\
{[0.432]}\end{array}$ & $\begin{array}{r}3.461^{* *} \\
{[0.535]}\end{array}$ & $\begin{array}{r}3.381^{* *} \\
{[0.491]}\end{array}$ & $\begin{array}{r}5.156^{* *} \\
{[1.207]}\end{array}$ & $\begin{array}{r}4.984^{* *} \\
{[0.996]}\end{array}$ \\
\hline $\begin{array}{l}\text { Educational controls } \\
\text { Work activity controls } \\
\text { Demographic controls } \\
\text { Industry fixed effects }\end{array}$ & $\begin{array}{l}\text { incl. } \\
\text { incl. } \\
\text { incl. } \\
\text { incl. }\end{array}$ & $\begin{array}{l}\text { incl. } \\
\text { incl. } \\
\text { incl. } \\
\text { incl. }\end{array}$ & $\begin{array}{l}\text { incl. } \\
\text { incl. } \\
\text { incl. } \\
\text { incl. }\end{array}$ & $\begin{array}{l}\text { incl. } \\
\text { incl. } \\
\text { incl. } \\
\text { incl. }\end{array}$ & $\begin{array}{l}\text { incl. } \\
\text { incl. } \\
\text { incl. } \\
\text { incl. }\end{array}$ & $\begin{array}{l}\text { incl. } \\
\text { incl. } \\
\text { incl. } \\
\text { incl. }\end{array}$ & $\begin{array}{l}\text { incl. } \\
\text { incl. } \\
\text { incl. } \\
\text { incl. }\end{array}$ & $\begin{array}{l}\text { incl. } \\
\text { incl. } \\
\text { incl. } \\
\text { incl. }\end{array}$ & $\begin{array}{l}\text { incl. } \\
\text { incl. } \\
\text { incl. } \\
\text { incl. }\end{array}$ & $\begin{array}{l}\text { incl. } \\
\text { incl. } \\
\text { incl. } \\
\text { incl. }\end{array}$ & $\begin{array}{l}\text { incl. } \\
\text { incl. } \\
\text { incl. } \\
\text { incl. }\end{array}$ & $\begin{array}{l}\text { incl. } \\
\text { incl. } \\
\text { incl. } \\
\text { incl. }\end{array}$ \\
\hline Constant & & $\begin{array}{r}-0.278 \\
{[1.182]}\end{array}$ & $\begin{array}{r}-1.895 \\
{[1.990]}\end{array}$ & $\begin{array}{r}-6.179 \\
{[4.283]}\end{array}$ & $\begin{array}{c}-7.873^{*} \\
{[3.430]}\end{array}$ & $\begin{array}{r}-10.756 \\
{[6.154]}\end{array}$ & & & & & & \\
\hline $\begin{array}{r}\text { Observations } \\
\text { alphaest } \\
\end{array}$ & 8789 & 2508 & 2508 & 2508 & 2508 & 2508 & $\begin{array}{r}10509 \\
3.556 \\
\end{array}$ & $\begin{array}{r}10509 \\
3.485 \\
\end{array}$ & $\begin{array}{r}10585 \\
3.815 \\
\end{array}$ & $\begin{array}{r}10585 \\
3.761 \\
\end{array}$ & $\begin{array}{r}5623 \\
3.936 \\
\end{array}$ & $\begin{array}{r}5623 \\
3.773 \\
\end{array}$ \\
\hline
\end{tabular}

Note: Model 1 logit, odds ratios reported. Models 2-6 quantile regression. Models 7-12 negative binomial (Incidence Rate Ratios reported). Standard errors in brackets (clustered by industry in Models $1,7-12$ ). ${ }^{*}=$ sig. at $5 \%, * *=$ sig. at $1 \%$. Omitted categories: Startup; Bachelors degree. 